\title{
Law, Politics, and the New Deal(s)
}

\author{
Laura Kalman ${ }^{\dagger}$
}

\section{INTRODUCTION}

The metaphor of fatigue permeates the debate over the constitutional history of the New Deal. Prior to the publication of Bruce Ackerman's We the People: Transformations, the disagreement pitted "internalist" law professors, such as Barry Cushman and Richard Friedman," against "externalist" historians, such as William E. Leuchtenburg and myself." Now comes Ackerman, who, picking up on the metaphor of fatigue used by some of the participants, ${ }^{3}$ urges us to drop "the old and tired debate." 4

$\dagger$ Professor of History, University of California, Santa Barbara. I am very grateful to Bruce Ackerman, John Morton Blum, W. Elliot Brownlee, Barry Cushman, James Fleming, Barry Friedman, W. Randall Garr, John Jordan, Pnina Lahav, John Henry Schlegel, Gregory Silbert, and G. Edward White for their help with this Article. I also appreciate the opportunity to have presented it at Yale and the University of Texas Law Schools and the comments I received on those occasions.

1. See Barry Cushman, Rethinking the New Deal Court: THe Structure of a CONSTITUTIONAL REVOLUTION (1998); Barry Cushman, Doctrinal Synergies and Liberal Dilemmas: The Case of the Yellow-Dog Contract, 1992 SUP. CT. REv. 235; Barry Cushman, Rethinking the New Deal Court, 80 VA. L. REV. 201 (1994) [hereinafter Cushman, Rethinking the New Deal Court]; Barry Cushman, The Secret Lives of the Four Horsemen, 83 VA. L. REV. 559 (1997) [hereinafter Cushman, The Secret Lives]; Barry Cushman, A Stream of Legal Consciousness: The Current of Commerce Doctrine from Swift to Jones \& Laughlin, 61 FORDHAM L. REV. 105 (1992); Richard D. Friedman, Switching Time and Other Thought Experiments: The Hughes Court and Constitutional Transformation, 142 U. PA. L. REV. 1891 (1994). The characterization of the debate as one between internalists and externalists is Cushman's. See, e.g., CUSHMAN, supra, at 3-7. Ackerman describes it as one between legal realists and legalists. See 2 BRUCE ACKERMAN, We the PEOPLE: TRANSFORMATIONS 343 (1998).

2. See William E. Leuchtenburg, The Supreme Court Reborn: The Constitutional ReVOlution IN THE AGE OF ROOSEVElt (1995); LAURA KALMAN, THE STRANGE CAREER OF LEGAL LIBERALISM (1996).

3. Cushman wrote of the externalists in 1994: "Until we move beyond the traditional account, our understanding of the New Deal Court will continue to seem anachronistically unsophisticated in comparison with our understandings of other eras in the Court's history. For the past fifty years, we have heard reiterated a constitutional bedtime story with a happy ending for New Deal liberals." Cushman, Rethinking the New Deal Court, supra note 1, at 260-61. Responding to the article in his book, Leuchtenburg charged in a footnote that Cushman had "contemptuously dismissed the conclusion of two generations of scholars" and "reached that judgment without the benefit of any original research in the papers of the Justices, and, though he argued for approaching the question by examining the internal legal reasoning of the Court, without scrutinizing most of the cases of the era and, in particular, without coping with the 
In Part II of this paper, I explore the dispute between internalists, who point to doctrinal, intellectual causes in explaining constitutional change during the New Deal, and externalists, who stress political reasons. I do so to locate Ackerman's place within the controversy. In stressing the controversy's unimportance, Ackerman scolds both internalists and externalists for assuming "that the conflict between the Old Court and the New Deal" in 1935 and 1936, which set the stage for Roosevelt's effort to pack the Court in 1937, was "a waste of time." ${ }^{5}$ He claims that in resisting the "First New Deal," Roosevelt's legislative program of 1933, the Old Court was acting as it should: serving "as the conservative branch, leading

arguments of Justices such as Stone who had no doubt there had been a volte-face." LEUCHTENBURG, supra note 2, at 317-18 n.95. For my part, I produced what may be one of the world's longest footnotes saying Cushman's account was unpersuasive. See KaLMAN, supra note 2, at 348-51 n.70. For a discussion of the exchange between Leuchtenburg and Cushman, see G. Edward White, Cabining the Constitutional History of the New Deal in Time, 94 MICH. L. REV. 1392, 1412-13 (1996) (reviewing LEUCHTENBURG, supra note 2).

In a rare triumph for academic civility, both Leuchtenburg and Cushman drew back from the brink. Though much of the language in Cushman's book, RETHINKING THE NEW DEAL COURT: THE STRUCTURE OF A CONSTITUTIONAL REvolution, supra note 1 , is identical to that in Rethinking the New Deal Court, supra note 1, and to Cushman's other articles on which the book builds, the two sentences do not appear and the book steers away from causticisms about externalists (though Cushman's disagreements with us remain eminently clear). And the paperback edition of The Supreme Court Reborn adopts a more respectful attitude towards Cushman (though again, the points of disagreement remain apparent). As this essay suggests, my own attitude toward the debate has undergone some change. While I still believe the externalist position is the right one, I no longer find the internalist argument implausible and unpersuasive.

The New Deal's cousin, legal realism, offers a cautionary example of what can happen when scholars start referring to each other's accounts as "tired," and civility diminishes, rather than grows. (Here I follow Ronen Shamir in stressing the relationship between legal realism and the New Deal as "two interrelated forms of practice," as opposed to two coincidental ideas. See RONEN SHAMIR, MANAGING LEGAL UNCERTAINTY: ELITE LAWYERS IN THE NEW DEAL 213 n.18 (1995)). Writing in the 1930 Columbia Law Review, Karl Llewellyn condemned the work of Roscoe Pound for "at times" descending to "the level of bedtime stories for the tired bar." Karl Llewellyn, A Realistic Jurisprudence-The Next Step, 30 CoLUM. L. REv. 431, 435 n.3 (1930). With that shot, Llewllyn helped to read Pound out of the realist canon and spur Pound to reply in kind. In turn, that raised what might have been a reasoned and fruitful disagreement between scholars to shrill heights and guaranteed that Pound and the realists would talk past each other. The story is best told in N.E.H. HULL, ROSCOE POUND AND KARL LLEWELLYN: SEARCHING FOR AN AMERICAN JURISPRUDENCE 173-218 (1997). And that ensured scholars would spend decades puzzling over what separated sociological jurisprudence and legal realism. See, e.g., NEIL DUXBURY, PATTERNS OF AMERICAN JURISPRUDENCE 71-79 (1995); LAURA KALMAN, LEGAL REALISM AT YALE, 1927-1960, at 46 (1986); G. Edward White, From Sociological Jurisprudence to Realism: Jurisprudence and Social Change in Early Twentieth-Century America, 5S VA. L. REV. 999 (1972). Ultimately, such polemics obscured the commonalities between the two impulses, while magnifying their differences, and sent scholarship down a blind alley. See MORTON J. HORWITZ, THE TRANSFORMATION OF AMERICAN LAW, 1870-1960, at 169-75 (1992).

4. 2 ACKERMAN, supra note 1 , at 343. Another interesting attempt to go beyond this debate comes in Stephen Gardbaum, New Deal Constitutionalism and the Unshackling of the States, 64 U. CHI. L. REV. 483 (1997), though as an “externalist," I would maintain that Gardbaum's imaginative challenge to our understanding of New Deal constitutionalism as "much less a nationalist revolution-with the connotations this label has for its attitude towards state authority - than it was a revolution in the power and permissible ends of government at all levels, state as well as national," id. at 486 , can be "shackled" to our "side."

5. 2 ACKERMAN, supra note 1 , at 291 . 
a principled challenge to a rising movement of revolutionary reform." 6 Ackerman thus legitimates the Court's role in a representative democracy and safely distances law from politics. But I contend that he also participates in the debate in spite of himself. Ironically, given his celebration of the prudential value of the Old Court, Ackerman largely makes the case for the externalists.

In Part III, I query Ackerman's insistence that we should challenge the "basic premises" of the internalist/externalist controversy. Though old, the debate is neither tired nor unimportant. It yields important insights into political and intellectual history; Ackerman trivializes it when he says it focuses on the subjective motivations of Justices. In fact, the controversy between the externalists and internalists involves the legal academy's most enduring concern (and, as I suggest in Part V, one of the leitmotifs of the Ackerman corpus): the relationship between law and politics. Further, one strength of Ackerman's work is that it points the way towards a manner in which we may usefully draw on both internalist and externalist accounts.

In Part IV, I focus more closely on the history Ackerman advances in support of his attempt to establish a "New Deal" for New Deal constitutional historiography. I argue that in celebrating the prudentialism of the Old Court, his account overemphasizes its role in bringing about social change of which Ackerman approves. Pace Ackerman, we can neither glorify Roosevelt's legislative program of 1935, the "Second New Deal," nor give all the credit for its passage to the Old Court. Nor does Ackerman consider the impact of the Court-packing episode on politics. Whatever its connection to the Court's "switch in time," the Court-packing plan helped close off Congress and the executive branch as routes for reform. Roosevelt's attempt to respond to the Old Court's resistance by packing it with additional Justices proved a political disaster, which helped end the push for social change in the executive and legislative branches for a quarter-century, beginning in 1938. Consequently, the reformist programs of the next era were carried out under the auspices of the judiciary, which created growing concern that American society was court-centered. That anxiety led to the resurrection of the "countermajoritarian dilemma," which has long consumed Ackerman and other constitutional theorists.

In Part V, I turn to the theoretical underpinnings of Ackerman's project. I maintain that Ackerman's externalist approach to Court-packing is in tension with his own jurisprudential internalism, which reflects his own roots in the legal process school. That is, despite his externalist approach to New Deal constitutional change, Ackerman is generally suspicious of court-centrism; wary of the idea that judging is a political act; and hostile to the claim that in an important sense, law is politics. I argue that his 
proposals for reclaiming the Constitution in the future reflect his attempt to separate law from politics and link him to both internalists and to the legal process school. Ultimately, his narrative and proposals are best understood as an outgrowth of his intellectual roots in the legal process tradition. In Part VI, I discuss my reaction to his proposals and speculate on some possible reasons for Ackerman's allegiances.

\section{ACKERMAN AND THE REIGNING NARRATIVES}

In We the People: Transformations, Ackerman continues the attack on "the Bicentennial myth" of American history as one republic that he began in We the People: Foundations. "While all lawyers recognize that the 1930 s mark the definitive constitutional triumph of activist national government," he explains, in the absence of formal Article $V$ amendment of the Constitution, "they tell themselves a story which denies that anything deeply creative was going on." ${ }^{8}$ Embracing "the myth of rediscovery as a convenient legal fiction," lawyers maintain that "[t]he founders of the welfare state in America were not Roosevelt and his Democrats but Marshall and other Federalists who built the constitutional foundations of national power" and whose relevance the New Dealers rediscovered after $1937 .^{10}$ In the words of Morton Horwitz, the legal community thus transformed the New Deal from "constitutional revolution" to "constitutional restoration." 11

Ackerman's assault on the "Bicentennial myth" deserves to carry the day. ${ }^{12}$ And I think it has. ${ }^{13}$ At least, Ackerman has received aid from surprising quarters. I follow Lawrence Lessig in aligning myself with "the odd alliance" of Ackerman and Richard Epstein. ${ }^{14}$ As Epstein puts it with characteristic pungency, there is only one response to the argument that the New Deal represents a return to the expansive view of the Commerce Clause set out in Gibbons v. Ogden: ${ }^{15}$ "No way." 16

In Foundations, Ackerman goes beyond challenging the "myth of rediscovery," the reigning popular narrative lawyers have created for "the

7. 1 BRUCE ACKERMAN, WE THE PEOPLE: FOUNDATIONS $34,42-43$ (1991).

8. 1 id. at 42 .

9. 2 ACKERMAN, supra note 1 , at 260 .

10. 2 id. at 259 .

11. Morton J. Horwitz, The Supreme Court, 1992 Term-Foreword: The Constitution of Change: Legal Fundamentality Without Fundamentalism, 107 HARV. L. REV. 30, 56 (1993).

12. See Stephen Griffin, Constitutional Theory Transformed, 108 YALE L.J. 2115 (1999).

13. But see id. (suggesting it has not yet triumphed).

14. Lawrence Lessig, Understanding Changed Readings: Fidelity and Theory, 47 STAN. L. REV. 395, 447 n.226 (1995).

15. 22 U.S. (9 Wheat.) 1 (1824).

16. Richard A. Epstein, The Proper Scope of the Commerce Power, 73 VA. L. REv. 1387, 1408 (1987). 
People." He also targets the "reigning professional narrative." 17 The professional, or scholarly, debate has concentrated on the timing of, and explanation for, the so-called New Deal "constitutional revolution." As Ackerman tells us, because the Court Roosevelt inherited "consisted of three blocs-four conservatives, three liberals, and a two-man center of Charles Evans Hughes and Owen Roberts,... [t]he reigning narrative naturally focuses on the flips and flops of the centrists as they struggled with constitutional perplexities." 18

Disagreement then breaks out between internalists, whom Ackerman terms "legalists," and externalists, whom he labels "legal realists," over the explanation for and the timing of the "flips and flops." The externalists/realists are read by Ackerman and others to suggest that Roberts and Hughes changed course abruptly in 1937. They made the "switch in time" and wrought the "constitutional revolution of 1937" because of the threat posed by FDR's Court-packing plan. Politics explained the Court's shift. The internalists/legalists, on the other hand, point to doctrinal changes that began before 1937 and continued thereafter to emphasize the plausible internal and intellectual reasons for the Court's journey. They acknowledge that the shift reflected "dramatic changes in constitutional jurisprudence," ${ }^{19}$ but they see it as more gradual and as more evolutionary than revolutionary. ${ }^{20}$

Ackerman stresses the importance of turning the spotlight away from the "hidden wellsprings" of "the subjective motivations of the two Justices." ${ }^{21}$ His "larger argument," he says, "does not depend on the ineffabilities of private motivation," 22 but demonstrates "how judicial resistance contributed to the democratic character of the outcome." ${ }^{23}$ In the process of making that larger argument, however, Ackerman indicates he will "incorporat[e] the insights of both sides without going to either extreme." ${ }^{24}$ I will evaluate Ackerman's larger argument on its own terms in Part IV. At present, I focus on how he enters the internalist-externalist debate despite himself.

17. 2 ACKERMAN, supra note 1 , at 290.

18. 2 id. at 290-91.

19. CUSHMAN, supra note 1 , at 5 .

20. See 2 ACKERMAN, supra note 1 , at 290-91.

21. 2 id. at 343 .

22. 2 id. at 486 n. 81 .

23. 2 id. at 312 .

24. 2 id. at 291 . 
I read Ackerman to embrace the externalist position. He talks of the "Old Court's early effort to say No to the New Deal" 25 in 1935 and 1936 by waging "continued war on the liberal welfare state" ${ }^{26}$ and striking down much of Roosevelt's 1933 legislative program. He emphasizes the loyalty of the majority of Justices to "the Lochnerian tradition," which awarded the market "constitutionally privileged status as a baseline." ${ }^{27}$ As he sees it,

the Justices were confronting a fundamental decision in March of 1937: on the one hand, they could stick to their guns in defense of the Lochnerian Constitution and run the clear and present danger that the People would formally repudiate the Court's traditional role in the separation of powers; on the other hand, they could eliminate the risk of hostile Article Five amendment by unequivocally recognizing the constitutional legitimacy of the New Deal vision of activist government. ${ }^{28}$

Two events explained the Court's decision. The first was the "[t]riggering [e]lection of 1936," in which FDR won a landslide victory; the second was Roosevelt's effort to capitalize on his popularity by making an "[u]nconventional [t]hreat" to the Court by proposing to pack it with additional Justices. ${ }^{29}$ What happened? According to Ackerman, thanks to the shift of Chief Justice Hughes and Justice Roberts, a majority of the Court embraced "the constitutional legitimacy of the New Deal vision of activist government." 30

Ackerman maintains that the 1937 decisions were markedly different from their predecessors. In opinion after opinion in 1936, the majority of the Court had said "Yes" to upholding the traditional "federalist and free market Constitution." " But, "with blinding speed," the majority changed its answer to "No" in 1937. For lawyers, the meaning was evident: "Despite the Court's quasi-traditionalist dicta, the partisans of the traditional Constitution were now always on the losing side." ${ }^{32}$

So far, Ackerman has proven even more externalist than the externalists. In the past, I have emphasized that, although FDR's stunning popularity had become apparent to all in the congressional elections of

25. 2 id. at 381.

26. 2 id. at 337.

27. 2 id. at 349, 366; see Lochner v. New York, 198 U.S. 45 (1905) (invalidating a New York law setting maximum hours for bakers on substantive due process grounds).

28. 2 ACKERMAN, supra note 1, at 342-43.

29. 2 id. at 359.

30. 2 id. at 343 .

31. 2 id. at 367.

32. 2 id. at 368 . 
1934, the Court nevertheless began striking down New Deal legislation. "Why would FDR's win in 1936 affect the Court?" 33 Like Leuchtenburg, ${ }^{34}$ I have also pointed out that, because the Court was not an issue in the 1936 campaign, it is implausible to think that the Justices would have interpreted the election results as a signal to mend their ways. ${ }^{35}$ Ackerman has gone us one better and argued, as some read Justice Roberts himself to have done later, ${ }^{36}$ that the Justices learned from "th' iliction returns." 37

Perhaps he is correct: Leuchtenburg doubts "that we shall ever have a satisfactory answer to that question," but he observes that Justice Van Devanter's papers indicate that "he and men like him seriously thought a Republican victory possible in 1936." ${ }^{38}$ William Forbath has demonstrated that though Roosevelt avoided the issue of the Court's decisions in 1936, the campaign was full of constitutional discourse and debate..$^{39}$ Further, two political scientists have shown that "[t] he possibility of a constitutional amendment ... became real following the 1936 elections." ${ }^{40}$ To them, it seems important that "the shift in Justice Roberts's position occurred after the election of 1936 but before Roosevelt's announcement." 41

33. KALMAN, supra note 2 , at 349 n.70.

34. See WILlIAM E. LeUChtenBuRG, The Origins of Franklin D. Roosevelt's "Courtpacking" Plan, in LEUCHTENBURG, supra note 2, at 82, 107.

35. See KALMAN, supra note 2, at 349 n.70 (noting that Roosevelt "deliberately avoided mentioning the Supreme Court in the 1936 campaign"). The impact of the 1936 election is the subject of Michael Nelson, The President and the Court: Reinterpreting the Court-Packing Episode of 1937, 103 POL. SCI. Q. 267, 281 (1988) (noting also that Roosevelt avoided the subject of the Court during the campaign). Nelson also maintains that "the political implications of the 1936 results were ambiguous," id. at 274 , and suggests that Roosevelt's large margin of victory was a handicap in that it imbued him with an arrogance that explained why he pursued Courtpacking in such a curiously impolitic way, see id. at 286, 293.

36. As Charles Leonard observed, "the Justice in his Harvard Lectures in 1951 did intimate that the Court took cognizance of the popular will." CHARLES A. LEONARD, A SEARCH FOR A JUDICIAL PHILOSOPHY: MR. JUSTICE ROBERTS AND THE CONSTITUTIONAL REVOLUTION OF 1937, at 144 (1971). Leonard himself attributed Justice Roberts's controversial 1937 decisions to his "honest search for the true meaning of the law," though he observed that in testifying before Congress in 1954, Justice Roberts alluded to the Court-packing plan, which caused "tremendous strain and threat to the existing Court, of which I was fully conscious." Id. at 180 (citing Hearing Before a Subcomm. of the Comm. on the Judiciary on Senate Joint Resolution 44, 83d Cong. 9 (1954) (statement of Justice Roberts)).

37. FINLEY PETER DUNNE, MR. DOOLEY's OPINIONS 26 (1906).

38. WILLIAM E. LeUCHTENBURG, THE FDR YEARS: ON ROOSEVELT AND HIS LEGACY 222 (1995).

39. See William E. Forbath, Caste, Class, \& Equal Citizenship, in MORAL PROBLEMS IN AMERICAN LIFE 167, 187-88 (Karen Halttunen \& Lewis Perry eds., 1998); see also ROBERT H. JACKSON, THE STRUGGLE FOR JUDICIAL SUPREMACY 177 (1941) ("The claim later made that the Supreme Court had not been an issue in the campaign is unfounded. It was merely an issue on which the President had no need to speak-one which his enemies could not win even by his default.").

40. Rafael Gely \& Pablo T. Spiller, The Political Economy of Supreme Court Constitutional Decisions: The Case of Roosevelt's Court-Packing Plan, 12 INT'L. REV. L. \& ECON. 45, 65 (1992).

41. Id. at 57; see also John W. Chambers, The Big Switch: Justice Roberts and the MinimumWage Cases, 10 LAB. HIST. 44, 57, 71-73 (1969) (suggesting that the Court followed election 
But for Ackerman, 1936 was just the beginning of the Court's lesson. Like Leuchtenburg, he also points to the importance of FDR's Courtpacking plan. He could "not care less" whether law or politics moved Hughes and Roberts, he reminds us. ${ }^{42}$ "The crucial fact is that they joined in creating opinions of the Court that had an obvious public meaning to the other participants in the constitutional conversation then raging about them." ${ }^{43}$ The Justices themselves "killed Article Five" "by negotiating their "switch in time," 44 thereby making both the Court-packing plan and the formal constitutional amendments bruited about by Senator Wheeler and others unnecessary. Whatever their reason for it, their "switch allowed the Court to put a new question into play in its dealings with the outside world: 'Now that we have switched, is it really necessary to consider seriously a fundamental change in the structure of the Supreme Court?" 45

Ackerman marks the Court's "switch" with the usual 1937 externalist landmarks. ${ }^{46} \mathrm{He}$ nods to the implications, for the demise of substantive due process, of the majority opinion overruling Adkins $v$. Children's Hospital ${ }^{77}$ in West Coast Hotel v. Parrish, ${ }^{48}$ which contemporaries thought so at odds with Roberts's opinion in Tipaldo. ${ }^{49}$ He places greater weight on the Court's broad view of the taxing and spending power in its decision upholding the unemployment insurance provisions of the Social Security

returns). According to Michael Parrish, "[t]he decisive question may be not whether Roberts 'switched' because of the court-packing message but what would have been the fate of Washington's law had Roosevelt not been reelected in November." Michael E. Parrish, The Hughes Court, the Great Depression, and the Historians, 40 THE HISTORIAN 286, 297 (1978).

42. 2 ACKERMAN, supra note 1 , at 343.

43. Bruce Ackerman, A Generation of Betrayal?, 65 FoRDHAM L. REV. 1519, 1531 (1997). But cf. infra note 116 and accompanying text (suggesting that the opinions did not have such an obvious meaning).

44. 2 ACKERMAN, supra note 1, at 345. Leuchtenburg is not willing to go that far. "Yet if it would be too much to conclude that the Court brought about the defeat of FDR's plan, it is accurate to say that this set of interventions by the Justices under Hughes' leadership," in the form of the Hughes letter to the Senate Judiciary Committee challenging the need for Court-packing, the 1937 decisions, and Justice Van Devanter's retirement, "greatly altered the topography of the struggle." William E. Leuchtenburg, The Nine Justices Respond to the 1937 Crisis, 1997 J. SUP. CT. HIST. 55, 71. Compare Alsop and Catledge's description of the atmosphere at the Court the day Justice Hughes announced Jones \& Laughlin:

[1] $t$ was as perfectly staged and cast a little incident as American history can show. Its only defect was a trace of overtheatricality. Its ironies-the Court's self-salvation by self-reversal, the Court's destruction of the President by giving him what he wantedwere just a trifle too cosmic. There was just a suspicion of the Eugene O'Neill touch.

JOSEPH ALSOP \& TURNER CATLEDGE, THE 168 DAYS 147 (1938).

45. 2 ACKERMAN, supra note 1 , at 343.

46. See 2 id. at $363-64$.

47. 261 U.S. 525 (1923) (invalidating the District of Columbia's minimum wage for women and children as a due process violation).

48. 300 U.S. 379 (1937) (overruling Adkins and upholding a Washington state minimum wage law for women).

49. Morehead v. New York ex rel. Tipaldo, 298 U.S. 587 (1936) (applying Adkins to strike down a New York minimum wage law for women as a violation of the Fourteen Amendment's Due Process Clause). 
Act, Steward Machine Co. v. Davis. ${ }^{50} \mathrm{He}$ stresses the majority's expansive approach to the Commerce Clause in its opinion upholding the Wagner Act in NLRB v. Jones \& Laughlin Steel. ${ }^{51}$

Chief Justice Hughes was prompted by politics, Ackerman suggests. True, the Chief Justice's decisions in 1937 "undoubtedly have some doctrinal roots," as the internalists maintain..$^{52}$ But a "narrowly legalistic account" of his behavior seems "naive" to Ackerman. ${ }^{53} \mathrm{He}$ contends:

All in all, Hughes's performance in 1937 is best seen as the product of constitutional statesmanship of the first order, by a man whose career-as governor of New York, secretary of state, and candidate for the presidency-enabled him to recognize the need for unconventional activity at a moment of grave crisis. ${ }^{54}$

What about Justice Roberts? According to Ackerman, the doctrinal reasons he later advanced for changing his Tipaldo vote in Parrish "simply don't hold up on legalistic grounds." 55 More to the point, Parrish is not a terribly important case anyway. It is a "typical phase-one product," 56 at most "an uncertain herald of revolutionary reform." 57 Roberts's relevance is not attributable to his vote in Parrish, so much as to "the remarkably consistent support he now gave to activist statutes that offended his previously proclaimed principles. If he had switched back to the conservative side in subsequent cases, the decision in Parrish would have been insufficient to defuse the crisis." 58

For Ackerman, the most important case of the trio is Jones \& Laughlin. "If Justice Roberts had joined the four conservatives in striking down the act, the Justices would have deprived the New Deal of its only creative solution to the proliferating sit-down strikes that were precipitating all-out class war in America's industrial heartland." ${ }^{59}$ Consequently, it does not surprise Ackerman that "the majority's decision in Parrish had no measurable impact on the Gallup Polls, but that its subsequent opinion in

50. 301 U.S. 548,591 (1937).

51. 301 U.S. 1, 30 (1937) (upholding the National Labor Relations Act of 1935, which guaranteed collective bargaining rights to employees producing goods for interstate commerce).

52. 2 ACKERMAN, supra note 1, at 484 n.47; see also id. at 364-65.

53. 2 id. at $486 \mathrm{n} .81$.

54. 2 id. at 484 n. 47 .

55. 2 id. at 486 n.81.

56. 2 id. at 364 .

57. 2 id. at 366 .

58. 2 id. at 364 .

59. 2 id. at 488 n. 34 . 
Jones \& Laughlin provoked an immediate and substantial decline in popular support for the President's court-packing initiative." ${ }^{60}$

\section{B. The Internalist Case}

What this account leaves out (and what I myself have ignored in the past) is that the internalists have made at least a plausible case for downplaying the doctrinal significance of all three cases to which Ackerman points. The stronger internalist case is made by Justice Roberts' and Chief Justice Hughes's champion, Barry Cushman, with Richard Friedman signaling agreement in most places, while showing greater uncertainty about Justice Roberts's motivations. Those two legalists accord Parrish even less importance than Ackerman does. Since Chief Justice Hughes had sided with the liberal three in Tipaldo, they waste no time on his position; his vote in Parrish was consistent with his vote in Tipaldo. The difference was that in Parrish, with Justice Roberts in tow, Justices Hughes, Brandeis, Cardozo, and Stone constituted a majority. Yet neither Cushman nor Friedman believes Justice Roberts "switched" his vote because of the 1936 election or Court-packing. Cushman asks the same question I did before reading Transformations: "If the Court felt no compunction about gutting the New Deal in the wake of the Democrats' spectacular success in 1934, one is led to inquire, why would the Court respond so differently to the election of 1936 ?" ${ }^{61}$ Further, as both internalists and externalists agree, Parrish was decided six weeks before FDR announced his plan to pack the Court, though Justice Stone's illness prevented the decision's announcement until afterwards. How, then, could Court-packing have influenced Justice Roberts?

60. 2 id. (citations omitted); see also ALSOP \& CATLEDGE, supra note 44 , at 175 (discussing how invalidation of Wagner Act would have caused labor lobbyists to "have flown to Capitol Hill like a nestful of angry wasps").

61. CUSHMAN, supra note 1, at 27; see also Friedman, supra note 1, at 1952 \& n.305 ("There is no reason to believe that the presidential election had any significant impact on Roberts's vote.").

62. I leave aside here the (in)famous "Roberts memorandum" justifying the switch. See Felix Frankfurter, Mr. Justice Roberts, 104 U. PA. L. REV. 311, 314-15 (1955). Like Chambers, I find the Roberts memorandum unconvincing. See Chambers, supra note 41, at 67. But see CUSHMAN, supra note 1, at 262-63 n.58 (defending the Roberts memorandum in light of Justice Roberts's record and the decisional culture of the Hughes Court). I also find plausible and provocative Michael Ariens's suggestion that Justice Frankfurter wanted to publish the Roberts memorandum to uphold the rule of law at a time when Brown was under attack for undermining it. See Michael Ariens, A Thrice-Told Tale, or Felix the Cat, 107 HARV. L. REV. 620, 645-51, 664, 669-75 (1994). I would, however, be reluctant to come as close as Ariens does to suggesting that Frankfurter himself may have made up the memorandum. See generally Richard D. Friedman, $A$ Reaffirmation: The Authenticity of the Roberts Memorandum, or Felix the Non-Forger, $142 \mathrm{U}$. PA. L. REV. 1985 (1994) (defending the authenticity of the Roberts memorandum). 
More important, for both Cushman and Friedman, the key case in destroying substantive due process was Nebbia v. New York, ${ }^{63}$ where, they say, Justice Roberts's majority opinion made possible a "revolution in due process doctrine" by discarding the public/private distinction. ${ }^{64}$ Consequently, to use Cushman's memorable sentence: "The empire of substantive due process was already in a state of collapse when the Parrish decision officially lowered the flag over its last colony." 65 Friedman does take Justice Roberts to task for "judicial timidity" in Tipaldo and for waiting until Parrish to board the bandwagon to overrule Adkins. ${ }^{66} \mathrm{He}$ is even willing to concede that perhaps Justice Roberts's vote in Parrish may be explained by the hostile reaction of the public to "Tipaldo itself," as opposed to the results of the 1936 election. ${ }^{67}$ Cushman, of course, is unwilling to go this far. ${ }^{68}$

Friedman and Cushman also observe that in the first Social Security case, Carmichael v. Southern Coal \& Coke Co. ${ }^{69}$ a five-person majority, including Justices Hughes, Roberts and the "liberal" bloc, upheld an Alabama unemployment insurance act under the unemployment provisions of the Social Security Act. Yet, according to them, disagreement did not necessarily imply lack of support for the principle of state unemployment insurance. In fact, they point out, Justices Sutherland, Van Devanter, and Butler's dissent offered the gratuitous opinion that the Wisconsin Unemployment Insurance Act was constitutional. ${ }^{70}$

For internalists, Steward Machine also marked no reversal of the federal government's taxing and spending power jurisprudence. Justice Roberts had approved a Hamiltonian approach to the General Welfare Clause in United States v. Butler, ${ }^{71}$ even as he overturned the Agricultural Adjustment Act for the majority. When he became part of the five-person majority in Steward, he was simply implementing that broad view. ${ }^{72}$ Further, some of the supposedly most conservative Justices approved of the

63. 291 U.S. 502, 536-37 (1934) (upholding emergency New York legislation during the Depression setting milk prices against claim it violated due process). I find Friedman and Cushman's explication of the relevance of Nebbia to Parrish illuminating. See, e.g., CUSHMAN, supra note 1, at 87-105; Friedman, supra note 1, at 1976 ("Nebbia played a somewhat larger and more visible role in" consolidating the Court's "receptive attitude towards economic regulation against due process objections" than "West Coast Hotel-not surprisingly, given that West Coast Hotel was essentially an application of Nebbia.").

64. CUSHMAN, supra note 1, at 225.

65. Id. at 105.

66. Friedman, supra note 1, at 1943-45. For Cushman's answer to Friedman on this point, see CUSHMAN, supra note 1 , at $97,262-63$ n.58.

67. Friedman, supra note 1 , at 1952.

68. See CUSHMAN, supra note 1 , at 97.

69. 301 U.S. 495 (1937).

70. See CUSHMAN, supra note 1, at 22; Friedman, supra note 1, at 1957 n.332.

71. 297 U.S. 1 (1936) (striking down the Agricultural Adjustment Act of 1933).

72. See Friedman, supra note 1, at 1955-57. 
unemployment insurance provisions of the Social Security Act: In his separate dissent in Steward, Justice Sutherland, joined by Justice Van Devanter, objected "only to certain easily correctable provisions of the Act." ${ }^{73}$ And in the last act of the unemployment and old age insurance trilogy, Helvering v. Davis, ${ }^{74}$ Friedman and Cushman note that Justices Van Devanter and Sutherland were part of the seven-person majority voting to uphold the old-age provisions of the Social Security Act. ${ }^{75}$

Once again, according to Cushman, the dates on which the decisions were handed down casts doubt on the notion that Roosevelt's assault against the Court intimidated Justice Hughes or Justice Roberts. Carmichael was decided ten weeks "before the Court-packing plan was known to any but the most intimate of Roosevelt's advisers." Steward and Helvering, the other two Social Security cases, "were handed down over three weeks after it was widely known that the committee would issue an adverse report and that the opposition had enough votes to defeat the bill in a vote on the Senate floor." "76

And Cushman does not believe that these cases are of first-rank importance. He points out that the opinion in Frothingham v. Mellon, ${ }^{77}$ written by the "conservative" Sutherland in 1923 for a unanimous Court, largely liberated the spending power from constitutional restraints long before Court-packing. "Here again Sutherland and company laid the constitutional foundation for the Great Society," Cushman observes, his tongue only partially in cheek. ${ }^{78}$

Nor do the legalists consider Jones \& Laughlin that significant. To Friedman, Chief Justice Hughes's concurrence in the 1936 case of Carter $v$. Carter Coal Co. ${ }^{79}$ was the aberration. True, Carter had significant consequences. It meant that Justice Sutherland's opinion for himself, Justices Roberts, Butler, and Van Devanter, adopting a restrictive approach to the Commerce Clause, carried the day. ${ }^{80}$ Yet Friedman argues persuasively that " [a]part from the odd opinion in Carter, Chief Justice Hughes's prior career pointed strongly to the result he achieved in Jones \& Laughlin." ${ }^{81}$ Justice Roberts's vote in Jones \& Laughlin with Justices

73. CUSHMAN, supra note 1, at 22; see also Friedman, supra note 1 , at 1957 (discussing the dissent by Justices Sutherland and Van Devanter).

74. 301 U.S. 619 , amended by 301 U.S. 672 (1937).

75. See CuSHMAN, supra note 1, at 22; Friedman, supra note 1, at 1957.

76. CUSHMAN, supra note 1 , at 23 .

77. 262 U.S. 447 (1923) (holding that federal taxpayers lacked standing to challenge the validity of federal appropriations acts unless they could demonstrate immediate personal injury).

78. Cushman, The Secret Lives, supra note 1, at 564.

79. 298 U.S. 238, 316 (1936) (striking down the wage and hour provisions of the Bituminous Coal Conservation Act of 1935).

80. See id. at 302 ("Mining is not interstate commerce, but like manufacturing, is a local business, subject to local regulation and taxation." (citation omitted)).

81. Friedman, supra note 1 , at 1965. 
Hughes, Brandeis, Cardozo, and Stone, Friedman concedes, is more difficult to reconcile with his previous "very right-wing opinion" in Alton striking down the Railroad Retirement Act. "Ro "Rerts's votes in the NLRB case probably reflected a change--but a legitimate change-in his views," which may have reflected his capacity for growth, rather than his surrender to political pressure. ${ }^{83}$

Unwilling to concede that Justice Roberts switched for even legitimate reasons, Cushman again travels further down the internalist path. $\mathrm{He}$ provides a dazzling reading of Chief Justice Hughes's "deformalization of the direct/indirect distinction" in Commerce Clause doctrine in Jones \& Laughlin, "the first current of commerce case the Court saw in the post-Nebbia era." 84 There, according to Cushman, Chief Justice Hughes drew on Justice Roberts's "deformalization of the public/private distinction" in Nebbia and synthesized it with the "current of commerce" ${ }^{85}$ doctrine articulated in the Progressive Era case of Swift \& Co. v. United States. ${ }^{86}$ Voilà: Jones \& Laughlin was consistent with what went before. Cushman further suggests that Chief Justice Hughes could legitimately and "easily have reached the same result [as it did in Jones \& Laughlin] with the current of commerce theory," 87 "the doctrinally consistent alternative so painstakingly prepared for them by the NLRB lawyers," ${ }^{88}$ but that the Chief Justice opted for the braver course of "[d]octrinal synthesis" instead. ${ }^{89}$ "Thus the Court... continued to operate within dominant stylistic, conceptual, and doctrinal paradigms." ${ }^{90}$ According to Cushman, the real changes in Commerce Clause doctrine had yet to occur.

And once again, Cushman asks, what about timing? Jones \& Laughlin was "handed down six weeks after it was clear that the opposition had sufficient support to sustain a successful filibuster against the bill." The conclusion seems obvious to him. Here, since "the justices had ample

82. Id. at 1968; see Railroad Retirement Bd. v. Alton R.R. Co., 295 U.S. 330 (1935) (holding that the Railroad Retirement Act of 1934 violated the Fifth Amendments's Due Process Clause and the Commerce Clause). Though agreeing that Justice Roberts "pummelled the Act to a bloody pulp" in Alton, Cushman nevertheless focuses on the fact that Justice Roberts's opinion left open the possibility that what Congress could not achieve through the Commerce Clause, it might nevertheless achieve through other means, as Congress did through its subsequent Carrier Taxing Act and Railroad Retirement Act, which "remain[] with us in modified form to this day." Barry Cushman, The Hughes Court and Constitutional Consultation, 1998 J. SUP. CT. HIST. 79, 89, 91 (1998).

83. Friedman, supra note 1, at 1973.

84. CUSHMAN, supra note 1 , at 170 .

85. Id. at $170-75$.

86. 196 U.S. 375, 398-99 (1905) (sustaining a Sherman Act injunction against cattle dealers' price fixing on the grounds that the cattle were in "current of commerce").

87. CUSHMAN, supra note 1, at 171. On this point, Friedman is skeptical. See Friedman, supra note 1, at 1968 n.393.

88. CUSHMAN, supra note 1 , at 171.

89. Id. at 175 .

90. Id. 
reason to doubt that the Court-packing plan had sufficient public and congressional support to pose a genuine threat to the Court as an institution, the plan is unlikely to have been the proximate cause" of the decision, just as it is implausible that the plan explained Parrish or the Social Security cases. ${ }^{91}$

\section{Ackerman's Response}

Against Cushman, ${ }^{92}$ Ackerman uses public opinion polls and Leuchtenburg's work demonstrating the longevity of Court-packing, in

91. Id. at 23.

92. According to Cushman, thanks to communications from Senators, the Justices were: aware as early as late February and probably at other times as well, that the opposition had enough votes to sustain a successful filibuster, if not to defeat the bill outright. It is therefore likely that the justices never saw the president's bill as a serious threat to the Court's independence, because the administration forces never held a card capable of trumping what appeared to be the opposition's one sure ace-the filibuster.

Id. at 20. However, "[t]he justices of course could not be certain that Roosevelt would not grasp one of his compromise alternatives [such as the Wheeler amendment]." Id. at 24. To Cushman, though, "from the outset and throughout the fight, then, it was clear that Roosevelt would cling stubbomly to his own bill rather than seizing on any of a number of possible compromise measures." Id. at 25. And when Senator Robinson finally did introduce a compromise at the end of the Court fight that Roosevelt could stomach,

it was doubtful that even a compromise bill could survive both a Senate filibuster and the House Judiciary Committee. The justices had ample reason to be confident that constitutional capitulation was not necessary to avert the Court-packing threat. Certainly they had reason to doubt that immediate, total, and unconditional surrender was required.

Id. Cushman's speculations are hardly unreasonable; as he notes, they are supported by both James MacGregor Burns and Lionel Patenaude. See id. at 234 n.109; see also JAMES MACGREGOR BURNS, ROOSEVELT: THE LION AND THE FOX 314 (1956) ("That the court bill probably never had a chance of passing seems now quite clear."); Lionel V. Patenaude, Garner, Sumners, and Connally: The Defeat of the Roosevelt Court Bill in 1937, 74 Sw. HisT. Q. 36, 51 (1970) (suggesting that, in the House, Sumners's opposition to Court-packing would probably have ensured the bill's defeat). However, Burns had not examined many of the manuscript sources that became available after his book was published, and Patenaude's account strikes me as Texascentric in focusing on the role of Texans in killing the Court Bill. (Consider that even in Texas, a bastion of opposition to Court-packing, Lyndon Johnson won his special election to Congress on April 10, 1937 by, in the words of a front page article in The New York Times, "shout[ing] ... his advocacy of President Roosevelt's court reorganization all over the Texas tenth district." LEONARD BAKER, BACK TO BACK: THE DUEL BETWEEN FDR AND THE SUPREME COURT 188 (1967) (quoting the newspaper account).

For the present, I stand by Leuchtenburg and Friedman, who depart from Cushman on the issue of Robinson's likelihood of success. According to Friedman, "some form of packing bill likely would have passed the Senate had Majority Leader Joseph Robinson not suddenly died ...." Friedman, supra note 1, at 1974. As Friedman explains in the accompanying note,

Robinson commanded the loyalty of many of his colleagues, and he hoped for a seat on the Court, a prospect that would be much more likely if the Court's membership were expanded-especially because Roosevelt was thought reluctant to name Robinson to the Court unless he were accompanied by more liberal nominees.

Id. at $1974 \mathrm{n} .411$; see also Richard D. Friedman, Chief Justice Hughes' Letter on Court-Packing, 1997 J. SuP. CT. HIST. 76, 84-85 (1997) (discussing the effect of Robinson's death on support for Roosevelt's bill in the Senate). 
some form, to devastating effect. ${ }^{93}$ To my mind, in addition to demonstrating that the 1936 elections may have influenced the Justices, ${ }^{94}$ Ackerman refutes Cushman's hypothesis that the President's plan was unlikely to have scared the Court into capitulation because the Justices had good reason to doubt Court-packing would survive Congress, ${ }^{95}$ even as Cushman persuasively shows how the Court drew on previous decisions to maintain doctrinal consistency. ${ }^{96}$ I close Ackerman's book more convinced than ever that FDR was correct to write that "[i]t would be a little naïve... to refuse to recognize some connection between these 1937 decisions and the Supreme Court fight." ${ }^{97}$ Like Leuchtenburg, Ackerman also suggests that Court-packing, or some threat to the Court in the form of a constitutional amendment, had a greater chance of success and over a longer period of time than Cushman claims. ${ }^{98}$

Indeed, one of the great virtues of the New Deal chapters in Transformations lies in the extensive attention Ackerman gives to Senator Wheeler's attempt to fight Court-packing. ${ }^{99}$ Ackerman's account makes Cushman's contentions about the vulnerability of the plan and the early end to any political threat to the Court less convincing. Whereas Cushman concentrates on the prestige Wheeler, as a Democrat, lent to the opposition, ${ }^{100}$ and FDR's unwillingness to play ball with Wheeler and

93. See 2 ACKERMAN, supra note 1 , at $324,333-36$.

94. See 2 id. at 311 .

95. See 2 id. at 24,315 .

96. See CUSHMAN, supra note 1, at 20-25. Caldeira, who maintains that Court-packing forced the Court into "an important jurisprudential retreat," writes that though public opinion polls did show a sharp drop in support for Court-packing after Jones \& Laughlin and Justice Van Devanter's resignation, "[i]t is not at all clear what the public would have done if the Court had insisted on continuing its opposition to the New Deal." Caldeira, supra note 93, at 1148-50.

97. Alpheus Thomas Mason, HaRlan Fiske STONE: PILlar OF THE LAW 463 (1956) (citation omitted).

98. See 2 ACKERMAN, supra note 1, at 324-42.

99. "Despite Wheeler's centrality, his constitutional views have not been given adequate attention," Ackerman rightfully observes. 2 id. at 321. The proposed Wheeler-Bone constitutional amendment noted:

In case the Supreme Court renders any judgment holding any Act of Congress or any provision of any such Act unconstitutional, the question with respect to the constitutionality of such Act or provision shall be promptly submitted to the Congress for its action at the earliest practicable date that the Congress is in session ...; but no action shall by taken by the Congress upon such question until an election shall have been held at which Members of the House of Representatives are regularly by law to be chosen. If such Act or provision is re-enacted by two-thirds of each House of the Congress to which such Members are elected at such election, such Act or provision shall be deemed to be constitutional and effective from the date of such reenactment.

2 id. When he testified before the Senate Judiciary Committee hearings, Wheeler proposed exempting decisions involving the Bill of Rights from his amendment. See Reorganization of the Federal Judiciary: Hearings Before the Committee on the Judiciary, United States Senate, 75th Cong. 485, 500 (1937) [hereinafter Reorganization of the Federal Judiciary]; infra note 102.

100. See, e.g., CUSHMAN, supra note 1, at 15 ("The Republicans recognized that they could defeat the president's plan only if they were able to draw over a sufficient number of ... Democrats. ... [T] hey hoped ... to find a liberal Democrat to champion their cause."). 
others promoting alternatives to the Plan, ${ }^{101}$ Ackerman reminds us that Wheeler sought to fight the fire of Roosevelt's Court-packing plan with fire, in the form of a constitutional amendment. ${ }^{102}$

The battle between the Senator and President, then, was not about whether the Court needed to be curbed. To a large extent, Ackerman reminds us, they "were on the same wavelength," ${ }^{103}$ both creating "mechanisms that sought to supplement the existing provisions of Article Five by limiting the Supreme Court to a suspensive veto rather than the absolute veto it had traditionally exercised over democratic legislation." 104 They disagreed "on a narrow, but fundamental issue" ${ }^{105}$ - whether the President, through judicial reorganization, or Congress, through constitutional amendment, should take the lead in reining in the Court. ${ }^{106}$

101. See id. at 23-24.

102. For a discussion of Wheeler's important role as leader of the coalition against Courtpacking and the Republicans' strategy of silent support, see JAMES T. PATTERSON, CONGRESSIONAL CONSERVATISM AND THE NEW DEAL: THE GROWTH OF THE CONSERVATTVE COALITION IN CONGRESS, 1933-1939 (1967); Marian C. McKenna, Prelude to Tyranny: Wheeler, F.D.R., and the 1937 Court Fight, 62 PAC. HIST. REV. 405 (1993). Interestingly, in his chapter describing his role in the Court-packing battle, "Saving the Court," Wheeler's autobiography barely mentioned his proposal of a constitutional amendment as an alternative route for achieving Roosevelt's objective, thus creating the impression he opposed the plan without suggesting an alternative. See BURTON K. WHEELER WITH PAUL F. HEALY, YANKEE FROM THE WEST 319-40 (1962) (explaining Wheeler's decision to oppose Roosevelt). At the Senate Judiciary Committee hearings in 1937, on the other hand, Wheeler repeatedly stressed his sympathy for Roosevelt's dilemma and his support for handling it with a constitutional amendment: "I want to accomplish the objectives which he has laid out and I want to help him." Reorganization of the Federal Judiciary, supra note 99, at 506. According to Wheeler, he and "practically all" of his forces "are willing to do away with their pride of authorship, and are willing to vote for any reasonable amendment which the administration will send down to the Congress or which the Judiciary Committee will report out." Id. at 509-10; see also id. at 495, 497, 498-500, 504, 509-12 (emphasizing support for a constitutional amendment). When Senator Key Pittman indicated that Wheeler should reach an accommodation with some of the other Senators, such as Judiciary Committee member Joseph O'Mahoney, who had introduced alternative constitutional amendments, Wheeler indicated his willingness to do so. See id. at 510. Wheeler subsequently joined with O'Mahoney in recommending adoption of the following amendment: "No law of the United States or of any State shall be held to be unconstitutional by any inferior court, and not by the Supreme Court unless two-thirds of the members thereof shall specifically and by separate opinion find it so beyond a reasonable doubt." Id. at 1074.

103. 2 ACKERMAN, supra note 1 , at 323.

104. 2 id. at 322 .

105. 2 id. at 324.

106. See $2 \mathrm{id}$. Which proposal, Roosevelt or Wheeler's, was more radical? See GARY DEAN Best, The Critical Press and the New Deal: The Press Versus Presidential Power, 1933-1938, at 114-16, 120-24 (1993) (discussing the contemporary argument that Roosevelt's Court-packing plan represented a march towards dictatorship); $c f$. BAKER, supra note 92, at 140 (arguing that Wheeler's proposal "undoubtedly was the more dangerous to the American system of government. If the principle of a Congressional veto over Supreme Court decisions were written into the Constitution, it could not be revoked except with great difficulty. The loss of the Court's power would be nearly as permanent as anything can be in the American system of government.... If the Roosevelt plan passed, however, the Supreme Court would have the opportunity to regain its independence at a later time" because once FDR had made his new appointments to the bench, "there would be no way the President could touch them."). For 
Refusing to be drawn into the "morass" of the internalist-externalist debate, ${ }^{107}$ however, Ackerman does not seriously engage with the internalists about the doctrinal underpinnings of the three 1937 cases. $\mathrm{He}$ limits himself to giving their emphasis on Nebbia the back of his hand. ${ }^{108}$ Further, he flatly insists Justices Hughes and Roberts's votes in Jones \& Laughlin, delivered at a time when they had "full knowledge of Roosevelt's threat," were "blatant[ly] inconsisten[t]" with their earlier actions in Carter v. Carter Coal Co. ${ }^{109}$ Of course, the Court spoke "the language of continuity," though their very holdings bespoke "the fact of rupture," Ackerman acknowledges. ${ }^{110}$ The Justices had reached "Phase One" of a turning point. ${ }^{111}$

\section{1937's Aftermath}

Here, Ackerman believes he shifts to the internalist side, emphasizing that the Court had more work to do to bring rupture. One point of the debate between externalists and internalists (the more important one, by my lights) concerns the reasons for the Court's shift: politics or doctrine. But timing plays an important part in the dispute as well. ${ }^{112}$ According to Ackerman, the externalists find a constitutional "revolution" of 1937. The abruptness of the change lends credence to their explanation that political pressure caused it. The internalists point to an "evolution" in constitutional doctrine that began before 1937 and continued afterwards to show that the political forces, which buffeted the Court in 1937, could not have explained the changes in doctrine.

Ackerman maintains that he converges with the internalists in saying the "paradigm shift" was not apparent until the early 1940s. ${ }^{113}$ According to Cushman:

It was the replacement of the Nine Old Men with younger men who had more recently come to legal maturity-men who, though not

Ackerman's discussion of the unworkability of the Wheeler amendment, see 2 ACKERMAN, supra note 1 , at 349 .

107. See 2 ACKERMAN, supra note 1 , at 486 n. 81 .

108. See 2 id. at 489 nn.37-38. For one answer the internalists might suggest to Ackerman's cavil, see CUSHMAN, supra note 1, at 256-58 n.76; and Friedman, supra note 1, at 1922 \& n.150.

109. 2 ACKERMAN, supra note 1 , at 488 n.34.

110. 2 id. at 363 .

111. 2 id. at 362 .

112. As Cushman indicates:

The conventional historical wisdom makes two distinct claims: first, that the Supreme Court suddenly and substantially reversed its position in the cases decided in the spring of 1937; and second, that this reversal was a political response to such external political pressures as the 1936 election and the Court-packing plan.

CusHMAN, supra note 1, at 5 (citations omitted).

113. 2 ACKERMAN, supra note 1 , at 488 n.26. 
without difficulty, were able to break free of an older constitutional vocabulary and embrace a new conception of the judicial function-that brought forth a new paradigm for commerce clause jurisprudence. This-not the plot of the conventional story of capitulation to external political pressure-was the "structure" of the constitutional revolution. ${ }^{114}$

The irony is not lost on Cushman. What it means is that externalists, who claim the Supreme Court followed the election returns, are correct, "not because the results of the 1936 election persuaded the Nine Old Men to ratify the New Deal, but because the Democratic victory enabled Franklin Roosevelt, through the power of appointment, to refashion the High Court in his own image." 115

Certainly no externalist has published the kind of extended treatment of Commerce Clause doctrine after 1937 that Cushman has. The ample evidence Cushman provides of contemporary reaction seems to undercut Ackerman's insistence that the 1937 decisions possessed obvious public meaning; ${ }^{116}$ some commentators thought that even after 1937, Schecter ${ }^{117}$ and Carter Coal remained good law. ${ }^{18}$ Cushman also convincingly shows that Justice Roberts could have gone along with labor decisions the Court handed down in the wake of the Wagner Act, ${ }^{119}$ for example, "without having an experience akin to that of Paul on the road to Damascus." ${ }^{220}$ So, too, Cushman's careful explication of Court memoranda demonstrates that Darby was no mere "footnote to Jones \& Laughlin, a foregone conclusion entailed by a revolutionary decision taken in 1937." 121 And, according to

114. CUSHMAN, supra note 1 , at 224.

115. Id. at 224; see also Wickard v. Filburn, 317 U.S. 111 (1942) (upholding the Agricultural Adjustment Act of 1938 against the challenge that federal power to regulate commerce did not extend to a farmer who produced and consumed wheat he never marketed); United States v. Darby, 312 U.S. 100 (1941) (upholding the application of the Fair Labor Standards Act of 1938, which provided wages and hours regulation for all employees in industries involving products shipped in interstate commerce, to the hours and wages of workers in a Georgia lumberyard, whose operations were exclusively intrastate, and overruling Hammer v. Dagenhart, 247 U.S. 251 (1918)).

116. But cf. Barry Friedman, The New Deal, and the Separation of Law and Politics (The History of the Countermajoritarian Difficulty, Part II C) 74 (unpublished manuscript, on file with The Yale Law Journal) ("Did the general public think the Court 'switched' direction? The answer to the question is a resounding 'yes."').

117. A.L.A. Schecter Poultry Corp. v. U.S., 295 U.S. 495 (1935).

118. See CuSHMAN, supra note 1, at 179. But see David A. Pepper, Against Legalism: Rebutting an Anachronistic Account of 1937, 82 MARQ. L. REV. 63, 138 (1998) (arguing that academic "Court observers generally agreed-some openly, others more subtly-on the cause of the switch: the crescendo of political events of 1936 and early 1937"). Pepper contrasts their reaction to the 1937 decisions to their "generously cautious response" to Nebbia and Blaisdell. Id. at 136.

119. See CuSHMAN, supra note 1 , at 184.

120. Id. at 189 .

121. Id. at 209. 
Cushman, it was only with Wickard that Justice Jackson was ready to acknowledge privately that "[w]e have all but reached an era in the interpretation of the commerce clause of candid recognition that we have no legal judgment upon economic effects which we can to oppose to the policy judgment made by Congress in legislation." 122 Only now was Justice Jackson ready to cross the "jurisprudential Rubicon" "23 "at high noon." 124

Where Cushman concentrates on the revolution in Commerce Clause jurisprudence that Darby and Wickard together represented, ${ }^{125}$ Ackerman also points to two other seminal "Phase Two" events in $1938 .{ }^{126}$ They are the "root-and-branch repudiation of the premises of Lochnerian thought" 127 in Erie, ${ }^{128}$ and, of course, Carolene Products, ${ }^{129}$ which "announced a fundamental change in the rules of the game" 130 by saying that the Court would uphold all economic legislation, absent a showing that it did not rest on a "rational basis." ${ }^{131}$ Like Cushman, though, Ackerman considers the revolution complete only with Darby-which "operated as the functional equivalent of a formal amendment" by boldly burying Hammer $v$. Dagenhart ${ }^{132}$-and with Wickard. ${ }^{133}$ Only then did the Court definitively inter Lochner and the Lochner Court, making clear "its sweeping affirmation of national regulatory authority." 134

Thus, Ackerman refuses to join Cushman and Friedman in saying the Court's shift began well before Roosevelt proposed to pack the Court. Rather, he argues that "Phase One" of the Court's shift became evident after the President introduced his Court-packing plan in 1937, at a time

122. Id. at 217 (quoting Robert Jackson, Memorandum for Mr. Costelloe, Re: Wickard Case 15 (July 10, 1942) (on file with the Library of Congress, Jackson MSS, Box 125)).

123. Id. at 217 .

124. Id. at 218.

125. See id. at 208-25.

126. 2 ACKERMAN, supra note 1 , at 368.

127. 2 id. at 370 (emphasis added).

128. Erie R.R. Co. v. Tompkins, 304 U.S. 64 (1938).

129. United States v. Carolene Prods. Co., 304 U.S. 144 (1938).

130. 2 ACKERMAN, supra note 1 , at 369 .

131. Carolene Prods., 304 U.S. at 152. According to Ackerman, the famous footnote 4, 304 U.S. at 152-53 n.4, of Carolene Products "offered up a theory of New Deal democracy as an organizing framework" as something of a "trial balloon[]," whose implications would "take years" to work out. 2 ACKERMAN, supra note 1 , at 369 . "While judges should defer to the legislature in ordinary economic disputes, 'a more exacting judicial scrutiny' might be required when the democratic process malfunctioned-either when the majority denied opponents crucial political rights or when legislation was motivated by prejudice against 'discrete and insular minorities." Id. For the argument that bifurcated, two-tiered judicial review originated not in Carolene Products but in the free speech/civil liberties decisions of the Court in the period immediately after World War I, see G. Edward White, The First Amendment Comes of Age, 95 MiCH. L. REV. 299 (1996); and G. Edward White, The Constitution and the New Deal: A Reassessment, ch. VI (unpublished manuscript, on file with The Yale Law Joumal) [hereinafter White, Reassessment].

132. Ackerman, supra note 43 , at 1534 .

133. See 2 ACKERMAN, supra note 1 , at $374 \mathrm{n} . *$

134. 2 id. at 374. 
when some threat to the Court was very much alive. But he stands with Cushman in stressing that the revolution in New Deal jurisprudence was not wholly evident until "the opinions of the early 1940s" 135 (though Ackerman presents Wickard as a footnote to Darby literally, ${ }^{136}$ whereas for Cushman, Wickard is perhaps an even greater watershed). ${ }^{137}$

Speaking to the Association of American Law Schools recently, Ackerman amplified his point about the significance of the 1940s decisions. Unlike the externalists, he is no 1937 "fetishist," he said. ${ }^{138}$ The "aftermath" of 1937 was important too, ${ }^{139}$ as Roosevelt took advantage of vacancies to select new Justices who were "public adherents of the New Deal philosophy of activist government" and who shared his "constitutional ideology." ${ }^{140}$ The President changed the face of the Court, "redeeming the voice of the People by a series of transformative appointments." 141

Ackerman and Cushman may be unfair to the externalists here. True, some externalists have acted as if 1937 was watershed, and what followed, denouement. True, the previous generation of externalists-men such as Corwin and McCloskey-did speak of the "constitutional revolution of 1937." ${ }^{142}$ True, Leuchtenburg did so in the past ${ }^{143}$ and still does sometimes. ${ }^{144}$ But at present, Leuchtenburg is more likely to emphasize the constitutional revolution of 1937 as a beginning, ${ }^{145}$ and he has always

135. 2 id. at $488 \mathrm{n} .26$.

136. See 2 id. at $374 \mathrm{n}$.*.

137. See CUSHMAN, supra note 1 , at 212-24.

138. Bruce A. Ackerman, Address at the 1998 Association of American Law Schools Annual Meeting, Law \& Interpretation: Interpreting “ 1937" (Jan. 1998), Tape 181.

139. Id.

140. 2 ACKERMAN, supra note 1 , at $352-53$.

141. 2 id.

142. EDWARD CORWIN, CONSTITUTIONAL REVOLUTION, LTD. 12, 64 (1941) (referring to the "constitutional revolution" in 1937); ROBERT G. MCCLOSKEY, THE AMERICAN SUPREME COURT 174 (1st ed. 1960); see also EDWARD S. CORWIN, COURT OVER CONSTITUTION 129 (1938) (finding a "revolution in our constitutional law which was inaugurated by the New Deal"). Corwin did, however, point to the antecedents of the constitutional revolution in cases such as Nebbia. See Edward CORWIN, CONSTITUTIONAL REVOLuTION, LTD. 75-76 (1941).

143. See, e.g., WILIAM E. LeUChTENBURg, The Great Depression and the New Deal, in LEUCHTENBURG, supra note 38, at 209, 229 (speaking in terms of a "Constitutional Revolution of 1937"). Leuchtenburg reiterates the point elsewhere:

There is no doubt at all, if you take the range of opinions from 1935 through 1937 the Court's attitude toward the commerce clause in the Schechter and Carter cases contrasted with its view in Jones and Laughlin, or the Rail Pension and Butler decisions contrasted with the Social Security rulings, that what political scientists have called a 'Constitutional Revolution' took place.

Id. at 222.

144. See, e.g., WILliam E. LeUChtenBURG, The Constitutional Revolution of 1937, in LEUCHTENBURG, supra note 2 , at 213.

145. See, e.g., id. at 236 ("In 1937 the Supreme Court began a revolution in jurisprudence that ended, apparently forever, the reign of laissez-faire and legitimated the arrival of the Leviathan State." (emphasis added)); id. at 224 (discussing United States v. Darby, 312 U.S. 100 (1941)). 
believed transformative appointments were important to the product of the Roosevelt Court. ${ }^{146}$ For my part, I find persuasive both the emphasis on evolution from 1937 to 1942, rather than revolution in 1937, and the point that the real change only occurred as Roosevelt appointed his Justices to the Court.

If I am right in saying that externalists are not " 37 fetishists," then Ackerman deserves the chair at the head of the externalist table. Even if I am wrong and am engaging in wishful thinking by suggesting that externalists do not fetishize 1937, Ackerman is still enough of an externalist to deserve a seat at the externalist table. But he does not want either place. $\mathrm{He}$ contends that we should abandon this debate because it is tired and unimportant.

\section{WHAT TO DO?}

\section{A. Can't We All Get Along?}

Should we drop the externalist-internalist controversy because it is futile and going nowhere? It is true we are fighting an old battle. A generation ago, it pitted internalists, such as Chief Justice Hughes himself,,${ }^{147}$ his most well-known biographer, ${ }^{148}$ and the high priests of legal process, ${ }^{149}$ against externalists, such as Edward Corwin, ${ }^{150}$ Benjamin Wright, ${ }^{151}$ Alpheus T. Mason, ${ }^{152}$ and Robert McCloskey. ${ }^{153}$ As Michael Parrish has shown, ${ }^{154}$ the two great political historians of the New Deal who wrote about the Court, ${ }^{155}$ Leuchtenburg and Schlesinger, ${ }^{156}$ built on the

146. See William E. LeuchtenBuRg, FDR's “Court-packing" Plan, in LeUChtenBuRg, supra note 2, at 154; WILLIAM E. LEUCHTENBURG, The Constitutional Revolution of 1937, in LEUCHTENBURG, supra note 2 , at 220.

147. See The Autobiographical Notes of Charles Evans Hughes 311-13 (David Danielski \& Joseph Tulchin eds., 1973).

148. See 2 MERLo PuSEY, Charles EVANS Hughes 766-72 (1951).

149. See, e.g., Frankfurter, supra note 62, at 311; Paul Freund, Charles Evans Hughes as Chief Justice, 81 HARV. L. REV. 4 (1967).

150. See, e.g., sources cited supra note 142.

151. See, e.g., BENJAMIN WRIGHT, THE GROWTH OF AMERICAN CONSTITUTIONAL LAW 200-08, 256-60 (1942).

152. See, e.g., AlPHEUS T. MASON, HARLAN Fiske STONE: PILlaR OF THE LAW 463-64 (1956); ALPEHUS T. MASON, THE SUPREME COURT: VEHICLE OF REVEÁLED TRUTH OR POWER GROUP, 1930-1937, at 49-52 (1951).

153. See MCCLOSKEY, supra note 142 , at 174-77.

154. See Parrish, supra note 41 , at $291-93,308$.

155. The third great political historian of the New Deal, John Morton Blum, wrote little about its jurisprudence, perhaps because he was busy unraveling its economic history. See 1 JoHN MORTON BLUM, FROM THE MORGENTHAU DIARIES: YEARS OF CRISIS, 1928-1938 (1959); 2 JOHN MORTON BLUM, FROM THE MORGENTHAU DIARIES: YEARS OF URGENCY, 1938-1941 (1964); 3 JOHN MORTON BLUM, FROM THE MORGENTHAU DIARIES: YEARS OF WAR, 1941-1945 (1967); JOHN MORTON BLUM, ROOSEVELT AND MORGENTHAU: A REVISION AND CONDENSATION OF FROM THE MORGENTHAU DIARIES (1970). 
insights of Corwin and company (though I believe Parrish underestimates the extent to which the legal process school influenced Schlesinger) ${ }^{157}$ It is equally true that we may never know who is right, though Leuchtenburg's two-volume history of Court-packing may yield some definitive answers from the archives.

But the debate is so vibrant now that abandoning it would prove unfortunate, especially since Ackerman gives us a way of moving it forward. "The legalists are right in insisting that the New Deal did not reconstruct constitutional law out of thin air; the realists are right in emphasizing the doctrinal revolution would not have happened without sustained Presidential leadership," he observes. ${ }^{158}$ That may sound like a nice way of saying "cease and desist," and surely that is what Ackerman wants us to do. But his insight possesses greater potential.

In showing exactly how the Justices went about reconstructing constitutional law, Cushman and Friedman have performed an enormous service. As brilliantly as any formalist Harvard law professor at the turn of the century, they have reconciled cases that once seemed irreconcilable. I might now concede that portions of the shift began before 1937. McReynolds was partially correct when, to quote Cushman, he "wrote despairingly to former Solicitor General James M. Beck that Nebbia, in tandem with Home Bldg. \& Loan Assn. v. Blaisdell, ... marked 'the end of the constitution as you and I regarded it. An alien influence has prevailed." ${ }^{159}$ In restrospect, we can see that influence, as the clash over a "living Constitution" between Chief Justice Hughes's majority opinion in Blaisdell and Justice Sutherland's dissent reflected, ${ }^{160}$ and as G. Edward

156. In addition to LEUCHTENBURG, supra note 2, see LEUCHTENBURG, supra note 38 , at 231-40; and ARTHUR SCHLESINGER, JR., THE AGE OF ROOSEVELT: THE POLITICS OF UPHEAVAL 447-96 (1960).

157. See generally KALMAN, supra note 3, at 155 (1986) (discussing the influence of the legal process school on Schlesinger).

158. 2 ACKERMAN, supra note 1 , at 291.

159. CuSHMAN, supra note 1, at 229 n.20; see also Home Bldg. \& Loan Ass'n v. Blaisdell, 290 U.S. 398 (1934) (upholding the Minnesota Mortgage Moratorium Law of 1933 that provided for a conditional moratorium on debtors' mortgage payments against a charge that it violated the Contracts Clause).

160. Compare Chief Justice Hughes's argument about the Contracts Clause in Blaisdell with Justice Sutherland's response. According to Chief Justice Hughes:

It is no answer... to insist that what the provision of the Constitution meant to the vision of that day it must mean to the vision of our time. If by the statement that what the Constitution meant at the time of its adoption it means to-day, it is intended to say that a the great clauses of the Constitution must be confined to the interpretation which the framers, with the conditions and outlook of their time, would have placed upon them, the statement carries its own refutation. It was to guard against such a narrow conception that Chief Justice Marshall uttered the memorable warning- "We must never forget that it is a constitution we are expounding"- " a constitution intended to endure for ages to come, and consequently to be adapted to the various crises of human affairs."

290 U.S. at 442-43. In contrast, Justice Sutherland contended: 
White makes clear in his forthcoming reassessment of the Constitution and New Deal ${ }_{,}^{161}$ was modernism.

Yet if I am now more prepared to acknowledge that the "alien influence" of modernism had appeared at the Court than I was before reading Cushman and Friedman's work, I wonder if it had prevailed before 1937-1942. One job of the historian is to view matters as they must have seemed to actors at the time; and at the time, not everyone perceived either Nebbia or Blaisdell as a big deal for the New Deal. ${ }^{162}$ The Court fight was a symptom of the battle over whether to view the Constitution through a modernist lens. ${ }^{163}$ Thus, I would still emphasize the importance of politics to understanding "1937," the Court-packing episode.

A provision of the Constitution... does not admit of two distinctly opposite interpretations. It does not mean one thing at one time and an entirely different thing at another time. If the contract impairment clause, when framed and adapted, meant that the terms of a contract for the payment of money could not be altered [by passage of] a state statute enacted for the relief of hardly pressed debtors to the end and with the effect of postponing payment or enforcement during and because of an economic or financial emergency, it is but to state the obvious to say that it means the same now.

Id. at 448-49 (Sutherland, J., dissenting). Justices Hughes and Sutherland continued their argument in West Coast Hotel Co. v. Parrish, 300 U.S. 379 (1937). See 300 U.S. at 390 (Hughes, C.J.) (stating that the change in "economic conditions" since Adkins occasioned "fresh consideration" of the state's minimum wage statute); 300 U.S. at 403 (Sutherland, J., dissenting) (insisting that "to say ... that the words of the Constitution meant today what they did not mean when written - that is, that they do not apply to a situation now to which they would have applied then-is to rob that instrument of the essential element which continues it in force"); see also White, Reassessment, supra note 131, at 45-52.

161. White, Reassessment, supra note 131, ch. VII, 28-36. For a discussion of the significance of the majority and dissenting opinions in Blaisdell and their implications for modernism, see Lessig, supra note 14, at 457-61; White, Reassessment, supra note 131, at 28-36.

162. See Pepper, supra note 118, at 67 (suggesting that "even in 1934, Nebbia and Blaisdell held enigmatic places amid the Court's generally conservative jurisprudence" and, contending further, "that any potentially broad interpretation of those holdings rapidly disappeared amid strikingly divergent Court decisions that followed." Id. at 146. Even White observes that "a suggestion made by one of the Court's less visible justices in a police power/due process case involving price regulation [Roberts in Nebbia] would have been seen as less significant by contemporaries than a statement made by the Chief Justice of the United States in a case involving minimum wage legislation [Hughes in Parrish]." WHITE, supra note 131, ch. VII, n.98.

163. But cf. WHITE, supra note 131, ch. VII, at 71. White notes:

Rather than seeing the constitutional revolution of the New Deal as a product of the Court-packing crisis, it is more profitable to think of the Court-packing crisis as a product of a constitutional revolution, one whose revolutionary character was far deeper and wider than any "switch in time." By assuming that the Supreme Court of the United States could be 'packed with persons who would be sympathetic to the political goals of the Roosevelt Administrations, and who would translate that sympathy into constitutional doctrine, the proponents of Court-packing were taking as a given that America was a government of men, not laws. Theirs was a modernist, "living" view of constitutional interpretation (emphasis added).

Id. Clearly, White has made an important contribution in presenting the New Deal as a constitutional revolution in modernism. See also Lessig, supra note 14, at 453 (reaching a similar conclusion as White in emphasizing the significance of both "changes in the economic and social reality that law regulated" and "changes in law's understanding of itself" to understanding the changes wrought by the New Deal). See generally Daniel Hulsebosch, Note, The New Deal Court: Emergence of a New Reason, 90 COLUM. L. REV. 1973 (1990) (discussing the old Court's 
Morton Horwitz has pointed out that so as long as we read Leuchtenburg's marvelous essay about Justice Roberts's "almost medieval" conception of "the relation of employer and employee" in Alton (an opinion that strikes even Friedman as reactionary), ${ }^{164}$ it will remain difficult for us to understand the Justice Roberts of two years later without finding any explanation other than politics convincing. ${ }^{165}$ In my heart, I still believe the Justice Roberts of 1937 had undergone a jurisprudential lobotomy, though I am able to see that possibly he was more of a "man of law" than I had imagined. Like Leuchtenburg, I believe the Court beat "a strategic retreat ... largely in response to the Court-packing plan," led by Chief Justice Hughes, "a very adroit politician," obsessed with preserving his body's institutional integrity. ${ }^{166}$ Just as the New Deal saved capitalism by reforming it, so the Justices accelerated a process of reform in 1937, which saved the Court from Court-packing and transformed constitutional jurisprudence by 1942.

Does any of this matter? Of course it does. Ackerman trivializes the disagreement between externalists and internalists when he suggests that it simply concerns the subjective motivations of two Justices. At bottom, Horwitz also stresses, this debate is about the central issue of legal thought during the last sixty years, the relationship between law and politics. ${ }^{167}$ Our obsession with that issue grows out of the coincidence and confluence of legal realism and the New Deal, the synergy of law and politics during one of the most pivotal moments in American history. ${ }^{168}$

appreciation of changes in the economic and social reality that law regulated during the early days of the New Deal, which helps to explain the initial success of the emergency power doctrine in cases such as Blaisdell). Hulsebosch points to the roles played by the rise of totalitarianism and the long term nature of the Depression in causing the Court's abandonment of the emergency rationale by 1935-36. See id. at 2002, 2008. But I do not understand why one cannot believe that there was both a constitutional revolution and a "switch in time" at work and that the latter contributed to the former. See PHILlIP BobBitT, Constitutional Fate: THEORY OF THE CONSTITUTION 28 (1982) ("[T]he critical pathology [for the constitutional crisis] must be understood as developing in the disillusion that came with the realization that law was made by the Court."). Bobbitt reminds us that in 1937, Professor Frankfurter challenged Justice Roberts's vote in Jones \& Laughlin as vigorously as Justice Frankfurter tried to justify it later: "Now with the shift by Roberts," Frankfurter privately wrote Roosevelt during the Court fight, "even a blind man ought to see that the Court is in politics and understands how the Constitution is being judicially construed." Id. For a discussion of Frankfurter's contemporary reaction to what he then believed was an unprincipled switch, see JOSEPH P. LASH, DEALERS AND DREAMERS: A NEW LOOK AT THE NEW DEAL 302-16 (1988).

164. See LEUCHTENBURG, Mr. Justice Roberts and the Railroaders, in LEUCHTENBURG, supra note 2, at 26, 39; Friedman, supra note 1, at 1929.

165. See Morton J. Horwitz, Address at the 1998 Association of American Law Schools Annual Meeting, Law \& Interpretation: Interpreting “1937” (January 1998), Tape 182.

166. LeUCHTENBURG, The Great Depression and the New Deal, in LEUCHTENBURG, supra note 38 , at $209,223$.

167. See Horwitz, supra note 165 , at Tape 181.

168. See Parrish, supra note 41 , at 308. 


\section{B. Where We Stand}

Where we stand on the issue of law's relationship to politics reflects our jurisprudential proclivities and the location in the academy from which we write. Cushman's work has moved me away from a crude realism emphasizing the role of idiosyncrasy in explaining individual judicial decisions towards critical legal studies. ${ }^{169}$ For, as he set out to do, and as critical legal scholars have done, ${ }^{170}$ Cushman has demonstrated law's relative autonomy. ${ }^{171}$ And he has done so in the context of one of the critical legal scholars' favorite whipping boys-the public/private distinction, no less! $!^{172}$

But what does that mean? Did "law" and "doctrine" account for "1937"? Do they explain the behavior of Chief Justice Hughes and Justice Roberts? Perhaps, but not necessarily. In the instance of the Court fight, a critical legal scholar might conclude that relative autonomy functioned to maintain the hegemony of elites by saving the Justices from Court-packing.

I doubt Cushman set out to write a brief for critical legal studies. Rather, I imagine he intended to write one for those formalist turn-of-the-century Harvard law professors-or more probably, for their Legal Process successors who had to live in the post-realist, post-New Deal world. ${ }^{173}$ Cushman the law professor reminds us that insights about law's relative autonomy "are not the exclusive province of Gramscian Marxists and critical anti-functionalists." They also appear in "Roscoe Pound's ruminations on the 'tenacity of a taught legal tradition;'... in Frederic Maitland's equally alliterative aphorism, "taught law is tough law"'; and in Charles Curtis's insistence that the Old Court exemplified the "Legal Tradition." ${ }^{174}$ Cushman continues:

169. John Henry Schlegel first pointed out the connection between Cushman's articles and critical legal studies to me. Cushman has made that connection clearer in his book. See CuSHMAN, supra note 1 , at $40-41$.

170. See, e.g., Robert W. Gordon, New Developments in Legal Theory, in THE POLITICS OF LAW: A PROGRESSIVE CRITIQUE 281, 286 (David Kairys ed., 1982).

171. CUSHMAN, supra note 1 , at $40-41$.

172. See, e.g., BARBARA H. FRIED, THE PROGRESSIVE ASSAULT ON LAISSEZ FAIRE: ROBERT HALE AND THE FIRST LAW AND ECONOMICS MOVEMENT 91-99, 167-75, 212 (1998); HORWTZ, supra note 3, at 206-08; Joseph William Singer, Legal Realism Now, 76 CAL. L. REV. 465, 47794 (1988) (reviewing KALMAN, supra note 3, and criticizing me for neglecting the realists' assault on the public/private distinction); Laura Kalman, Eating Spaghetti with a Spoon, 49 STAN. L. REV. 1547, 1559 (1997) (reviewing NEIL DUXBURY, PATTERNS OF AMERICAN JURISPRUDENCE (1995), agreeing with Singer in part, and proposing we recognize the interrelationship between the public/private distinction and functionalism for the realists).

173. I emphasize that the key word here is "imagine." John Henry Schlegel pointed out to me that our lack of certainty about Cushman's politics in the world of the legal academy, where academics' politics are generally so clear, may be one reason his internalism makes us nervous.

174. CUSHMAN, supra note 1 , at 41 (quoting CHARLES CURTIS, LIONS UNDER THE THRONE 190-91 (1947)). 
These scholars have all been trying to remind us that legal history is not simply political history, or social history, or economic history; legal history is also intellectual history. Judges are participants not merely in a political system, but in an intellectual tradition in which they have been trained and immersed, a tradition that has provided them with the conceptual equipment through which they understand legal disputes. To reduce constitutional jurisprudence to a political football, to relegate law to the status of dependent variable, is to deny that judges deciding cases experience legal ideas as constraints on their own political preferences. ${ }^{175}$

As a still skeptical externalist, I have resolved to treat the internalists with greater respect. I do not go as far (of course!) as Cushman in maintaining that no "reductionist" model is sufficient to explain the New Deal Justices' behavior. The model that so irritates him may indeed account for the Justices' actions. But Cushman has made a convincing case that the reductionist model is not the only explanation. Sometimes precedents do guide results (recall, however, Llewellyn's discussion of sixty-four "available impeccable" techniques of handling precedent) ${ }^{176}$ Cushman has given us a story that will resonate with those who believe judges are not identical to politicians and will enrich their understanding of judicial motivation. By taking New Deal constitutional jurisprudence on its own terms and making sense of it, he has demonstrated that legal history can indeed be a genre of intellectual history. I simply continue to be interested in legal history as political, economic, and social history also.

The internalists might accord the externalists more respect too. They might ask why anyone would embrace the "reductionist model." The answer has to do with who we are: political historians. And that may make it as difficult for us to accept Ackerman's history as it is for us to drop our externalist model for an internalist one.

\section{ACKERMAN'S HISTORY}

\section{A. Ackerman's Account}

In place of the traditional debate, Ackerman advances an arresting historical thesis, which has the effect of emphasizing the difference between law and politics and providing a reassuringly positive role for the old Court in furthering the cause of democracy. The "New Deal revolution" broke

175. Id. at 41 .

176. Karl N. Llewellyn, The Common Law Tradition: Deciding Appeals 75-91 (1960). And sometimes legal opinions are grounded in doctrine (and sometimes politics, and sometimes both doctrine and politics). 
with Article $\mathrm{V}$ by replacing a congressional model of leadership with a presidential one and by using "transformative opinions as amendment-analogues," 177 he maintains. Further, the two developments were related. "Rather than appearing as an inexplicable formal breach of Article Five, the New Deal Court's development of transformative opinions was an organic response to the rise of Presidential leadership in higher lawmaking." 178

In the context of the New Deal, he contends these developments were all to the good, the Court's role in bringing them about salutary. Ackerman breaks with both externalists and internalists, who he insists, perhaps unfairly, ${ }^{179}$ have suggested that "the conflict between the Old Court and the New Deal was a waste of time." 180 To the contrary, he tells us, the Court's intransigence forced FDR to reevaluate his course. ${ }^{181}$ That was as it should be: In the context of "the dualist tradition, no movement for revolutionary reform can rightfully expect an easy victory for its transformative vision. It must earn its claim to speak for the People by repeatedly winning electoral support in the face of sustained constitutional critique." ${ }^{182}$ Thus, in testing the New Deal, the Old Court did not betray traditional American constitutionalism, but recovered it. The Court was fulfilling its "preservationist function." 183

How, exactly, did the Court ensure this process of reconceptualization by the President? By Ackerman's account, the First New Deal was truly radical. Next to everything else Congress approved, its "epochal decision to impose sweeping and continuing regulation on Wall Street seemed almost humdrum." 184 After all, "Congressional approval of the Tennessee Valley Authority inaugurated a national experiment with outright socialism." 185 Further, "the most important initiative of the first New Deal Congress," 186 the National Industrial Recovery Act, "proposed to abolish market

177. 2 ACKERMAN, supra note 1 , at 271 .

178. 2 id.

179. I certainly believe the conflict between the Old Court and the New Deal was a waste of time, and other externalists may also. But among the internalists, Cushman suggests that the conflict between the Old Court and the New Dealers forced the New Dealers to draft better and more lawyerly legislation. See infra note 192. I take Cushman's tone to be one of approval. In another article, he has emphasized the extent to which, "in ways that Roosevelt apparently did not fully appreciate, but which others did, the Court was in fact cooperating with the political branches in seeking to formulate constitutional solutions to the economic crisis of the 1930s." Cushman, supra note 82 , at 80 .

180. 2 ACKERMAN, supra note 1 , at 291 .

181. See $2 \mathrm{id}$. at 310,313. As I discuss below, see infra notes 227-229 and accompanying text, Ackerman creates the impression that the Court was the chief cause of the shift in emphasis he discerns between the legislation of 1933 and 1935.

182. 2 id. at 291.

183. See 1 ACKERMAN, supra note 7, at 10, 261-65.

184. See 2 ACKERMAN, supra note 1 , at 288 .

185. 2 id.

186. 2 id. 
capitalism and replace it with a corporatist structure under Presidential leadership." ${ }^{187}$ When the Court declared the Act unconstitutional two years later in A.L.A. Schechter Poultry Corp. v. United States, ${ }^{188}$ Roosevelt faced three choices.

First, he could beat a retreat and call on Congress to enact " a new and more modest legislative program that accepted the Court's constitutional critique." 189 Second, he could defiantly order Congress "to reenact (something like) the NIRA; then appeal to the People in 1936 for a mandate to insist on his initiatives despite the Court." ${ }^{190}$ Third, he could "rethink the New Deal. Was the centralizing style of Presidential corporatism really the best way to control the abuses and injustices of a free market economy?" 191

According to Ackerman, Roosevelt opted for the third route, embracing the "self-consciously constitutional" initiatives of the Second New Deal in 1935. ${ }^{192}$ That meant replacing "corporatism" with "nationalism," dropping "the all-embracing corporativism of the NIRA" and pursuing instead the kind of structural reforms he had favored with the Securities Acts of 1933 and $1934 .{ }^{193}$ Thanks to the Court, "the imperative of central planning" 194 would make way for the birth "of a new freedom, defined in the light of modern realities that would otherwise defeat the claims of equal opportunity" and that could be achieved only "through democratic control of the marketplace." ${ }^{195}$ Ackerman elaborates:

This Second New Deal marked an important change in constitutional course. Rather than seeking to displace the competitive market with the NIRA, Roosevelt and Congress now accepted the market as a legitimate part of the emerging economic order-so long as regulatory structures could be introduced to correct abuses and injustices defined through the democratic process. Thus, the Wagner Act gave disorganized workers new tools to bargain effectively with their bosses; the Holding Company Act eliminated abusive concentrations of big capital; the Social

187. 2 id. at 286.

188. 295 U.S. 495, 551 (1935).

189. 2 ACKERMAN, supra note 1 , at 296.

190. 2 id.

191. $2 \mathrm{id}$. at $296-97$.

192. $2 \mathrm{id}$. at 310 . Though Ackerman stays away from the debate about the impact of lawyering on the New Deal, raising it explicitly only in 2 ACKERMAN at 293, $478 \mathrm{n} .32$, he implicitly endorses Schlesinger's argument that one reason the legislation of the First New Deal did not survive Court scrutiny, while that of the Second New Deal did, was that the statutes of 1935 were better drafted. See id. at 293, 310. For Schlesinger's formulation, see ARTHUR M. SCHLESINGER, JR., THE POLITICS OF UPHEAVAL 393-95 (1960).

193. See 2 ACKERMAN, supra note 1 , at $298,302$.

194. 2 id. at 310.

195. 2 id. 
Security Act guaranteed all workers the prospect of a decent old age after their usefulness to the market was over.

... As the Democrats prepared for the 1936 elections, they would return to the voters as advocates of a regulated capitalism, proposing a series of focused structural initiatives by which the People might control, but not obliterate, the competitive market. ${ }^{196}$

In the meantime, the Court continued to contribute "to the democratic character of the ultimate outcome" by striking down other legislation in 1935 and 1936. That action had the effect of putting "Americans on notice that the New Deal was shaking the foundations-and that it was not too late to withdraw their mandate." ${ }^{197}$ Voters responded by all but canonizing Roosevelt.

In Ackerman's version, "the Old Court's early effort to say No to the New Deal made the People's Yes in 1936 more credible," 198 even to conservatives on the Court and in the Republican Party, ${ }^{199}$ and Roosevelt could then successfully threaten the Court. ${ }^{200}$ "With the switch in time, all three branches were now operating on the premise that the New Deal spoke for the People in enacting revolutionary reforms like the Wagner Act and Social Security Act." ${ }^{201}$ The New Deal had been both dialectically and dialogically legitimated as a constitutional moment. ${ }^{202}$

To preserve the momentum, Roosevelt now had to ensure that the Court would stay the course. Instead of using appointments to the Court for patronage purposes, he must take "constitutional ideology" into account in choosing Justices. ${ }^{203}$ And for the most part, the President did. With the exception of James Byrnes, he restricted "his nominations to public adherents of the New Deal philosophy of activist government" and created "a founding precedent of the modern republic" by "redeeming the voice of the People" through "transformative appointments." ${ }^{204}$

How did the Senate respond? Ackerman views the 1938 midterm election as a consolidating election where the Court was concerned, even as he acknowledges that "Republicans in the Senate failed to make the President's transformative strategy a campaign issue in 1938." ${ }^{205}$ Despite the emergence in 1938 of a conservative coalition in Congress that blocked reform in many areas, Republicans and Southern Democrats accepted "the

196. 2 id. at 302 .

197. 2 id. at 303.

198. 2 id. at 381 .

199. See 2 id. at 311 .

200. See 2 id. at 381.

201. 2 id. at 350 .

202. See 2 id. at 381 .

203. 2 id. at 352 .

204. 2 id. at 353.

205. 2 id. at 355. 
New Deal revolution in the courts" and Roosevelt's appointments. ${ }^{206}$ They rushed to confirm "three emphatic liberals to the Court in the next two years" ${ }^{207}$ _Justices Frankfurter, Murphy, and Douglas.

More strikingly, perhaps, in the presidential election of 1940, the Republicans turned to Wendell Willkie. His article in the Saturday Evening Post predicting that when the public understood that the Roosevelt Court's decisions "have made the United States a national and no longer a Federal Government, ... it will mightily rebel," helped propel him to "the center of Republican politics." Having won the nomination, however, Willkie proved "quite unwilling to make his jurisprudential essay in the Post the basis of a campaign onslaught against the New Deal Court," though perhaps he would have reacted to FDR's "series of liberal appointments" by beginning "a campaign for 'balance' on the Court" had he been elected. ${ }^{20 s}$

Yet Willkie was not elected. The year 1940 proved yet another consolidating election. Roosevelt's triumph against the Republican nominee's charges that a third term represented a move towards dictatorship freed the President to make still more transformative appointments. All his nominees "were confirmed without a single vote of opposition-the liberal Stone replacing Chief Justice Hughes, the liberal Jackson replacing Stone, the liberal Wiley Rutledge replacing the misplaced Byrnes replacing the conservative McReynolds." 209

For Ackerman, this story yields several lessons. Ordinary Americans understood and accepted "the constitutional significance of the Supreme Court's transformation." So did Republicans. Had they intended to make it an important issue in the 1940 presidential election, they would have selected someone, such as Robert A. Taft, "to raise the banner of old-style conservatism." They chose Willkie instead because they knew that was not what Americans wanted. "The Republican convention of 1940 correctly understood that the country was proud of the way in which it had weathered the storms that had destroyed so many democracies in Europe; and that it would have no patience with a party that had promised to fight to the bitter end for lost constitutional causes." 210

The tone is one of admiration for Roosevelt's achievement in circumventing Article V and "federalist formalisms." ${ }^{211}$ Ackerman hails the achievement of the New Dealers in devising "unconventional adaptations" that enabled "the citizenry to express sustained support for a more nationalistic, activist, pragmatic, and dialogic understanding of its

206. 2 id.

207. 2 id.

208. 2 id. at $356-57$.

209. $2 \mathrm{id}$. at 358.

210. 2 id.

211. 2 id. at 350 . 
commitments as a People." 212 What fascinates him is "the way Americans themselves conducted a political dialogue that finally led to the considered conclusion that the People had spoken." 213 Having defeated "the President's frontal assault on the Court's formal independence" in 1937, Republicans accepted Roosevelt's assertion that "the People had given him a mandate to constitutionalize the principles of New Deal Democracy" and acknowledged that "the People had indeed endorsed activist national government." 214

\section{B. Ackerman's Relationship to the Historiography}

What can we say about this picture? To me, though the execution seems flawed, the overall effect is often pleasing. As I have said, Ackerman has persuaded me that the 1936 election results may indeed have represented, and been interpreted as, a referendum on the Court. ${ }^{25} \mathrm{He}$ has strengthened my (already firm) conviction that the Court switched under pressure, even though that was not his mission. He has made me see 1937, if not what followed, as a constitutional moment.

I especially admire Ackerman's emphasis on the importance of the President's behavior in causing the three branches of government to cooperate in acknowledging that the people had spoken in 1937. It supports the point that Roosevelt did not display his usual willingness to compromise during the Court fight because of his unusual understanding that all three branches of government, in the President's words, must be " 'interdependent as well as independent, and that all three work together to meet the living generation's expectations of government." 216 Thus,

212. 2 id. "I refuse, then, to join a formalist lament at the failure of an earlier generation of Americans to announce their constitutional intentions through Article Five Amendments. My attitude is closer to celebration than disdain." $2 \mathrm{id}$. For the arguments that a constitutional amendment might have been more easily enacted than Roosevelt said, and that "[f]ailure to pursue amendment meant ... that the New Deal was not erected on as strong and solid a constitutional foundation as might well have been possible at the time," see DAVID E. KYVIG, EXPLICIT \& AUTHENTIC ACTS: AMENDING THE U.S. CONSTITUTION, 1776-1995, at 305, 314 (1994). Kyvig makes the point that "the changes that occurred in the 1930s lacked the clarity and specificity of constitutional amendments," id. at 289, a point developed with eloquence by Forbath in Caste, Class, and Equal Citizenship, supra note 39, though Forbath does not address the issue of whether a constitutional amendment might have redefined citizenship rights more broadly than Roosevelt and judicial decisions together did.

213. 2 ACKERMAN, supra note 1 , at 358.

214. 2 id. at 359.

215. Cf. KALMAN, supra note 2, at 348-51 n.70 (emphasizing the unimportant role of the Court in the 1936 campaign).

216. Torbjorn Sirevag, Rooseveltian Ideas and the 1937 Court Fight: A Neglected Factor, 33 HISTORIAN 578, 592 (1971) (citation omitted). Ackerman, who maintains that "[r]ather than contenting himself with an important role," Roosevelt wanted to be "all-important," might disagree with Sirevag's contention that the President sincerely held this view. 2 ACKERMAN, supra note 1 , at 381 . 
Ackerman has done what most liberal historians, for all our qualified admiration of Roosevelt, have been unable to do: He has made the President's conduct during the Court fight seem sensible!

Yet I find Ackerman's account overdetermined. It overemphasizes the role of the Court in bringing about social change that Ackerman considers positive. Like Zelig, the Court pops up everywhere, sometimes in places it does not belong.

Begin with the story of a First and Second New Deal provided in Transformations. Ackerman acknowledges neither that the idea of First and Second New Deals evokes different meanings for historians, ${ }^{217}$ nor that historians have challenged the suggestion of two separate New Deals. ${ }^{218}$ Instead, he has exaggerated the coherence of the First New Deal and created a distorted impression of the rupture it represented. Indeed, Ackerman implicitly acknowledges this when he cites the elderly Herbert Hoover at his most reactionary as the source for the claim that the TVA (which the old Court upheld by an eight-to-one vote!) ${ }^{219}$ represented "outright socialism." 220

The word "corporatism" is so protean (more so, even, than "liberalism") that it is unclear what Ackerman means by it. ${ }^{221}$ But I tend to

217. See, e.g., ERIC GOLDMAN, RENDEZvous WITH DESTINY 333-42, 361-67 (1953) (comparing the First New Deal to Theodore Roosevelt's New Nationalism, the Second to the New Freedom); Michael E. PARRISH, ANXIOUS DECADES: AMERICA IN PROSPERITY AND DEPRESSION 1920-1941, at 297-99, 338-39 (1992) (challenging idea of "First New Deal" with a coherent focus on national planning, but suggesting the 1935 legislation of the Second Hundred Days represented a "different New Deal, one more class-conscious than the first and much less interested in maintaining a broad consensus that had begun to dissolve"); BASIL RAUCH, THE HISTORY OF THE NEW DEAL 11 (1944) (maintaining that the First New Deal was concerned with recovery and the Second moved to the left by focusing on social justice); SCHLESINGER, supra note 192, at 393-95 (1960) (suggesting that the First New Deal combined a visionary emphasis on national economic planning with loose draftsmanship while the Second moved to the right by concentrating on the recovery of the free market and improved legal craftsmanship); William $\mathrm{H}$. Chafe, Women's History and Political History: Some Thoughts on Progressivism and the New Deal, VISIBLE WOMEN: NEW ESSAYS ON AMERICAN ACTIVISM, 101, 112-13 (Nancy Hewitt \& Suzanne Lebsock eds., 1993) (advancing a gendered interpretation of the two New Deals). Schlesinger has apparently been the historian who has most influenced Ackerman's understanding of the political history of the New Deal, though one can discern elements of Goldman's approach in Ackerman's interpretation as well. See, e.g., 2 ACKERMAN, supra note 1, at 302.

218. See ANTHONY J. BADGER, THE NEW DEAL: THE DEPRESSION YEARS, 1933-1940, at 94-99 (1989); WILLIAM E. LEUCHTENBURG, FRANKLIN D. ROOSEVELT AND THE NEW DEAL 163 (1963); LeUChTENBURG, The Great Depression and the New Deal, in LEUCHTENBURG, supra note 38 , at 216-17.

219. I am grateful to Barry Cushman for this reminder. See Ashwander v. Tennessee Valley Auth., 297 U.S. 288 (1936).

220. 2 ACKERMAN, supra note 1 , at 288,477 n.20.

221. See, e.g., DONALD R. BRAND, CoRPoRATISM AND THE RULE OF LAW: A STUDY OF THE NATIONAL RECOVERY ADMINISTRATION 18-22 (1988) (discussing definitions of corporatism); LEO PANITCH, Theories of Corporatism: Reflections on a Growth Industry, in WORKING-CLASS POLITICS IN CRISIS: ESSAYS ON LABOUR AND THE STATE 160 (1986) (noting "the profound lack of agreement on what the concept [of corporatism] actually refers to"). But cf. BRAND, supra, at 11 "scholars have unanimously referred to the National Recovery Administration... as 
agree with Colin Gordon that during the interwar years in America, "few corporatist solutions transpired beyond Herbert Hoover's [1920s] subject files." 222 Ackerman fails to acknowledge the National Recovery Administration's roots in the War Industries Board and "the vaguely corporatist vision of economic harmony that had emerged from World War I." ${ }^{223} \mathrm{He}$ ignores the fact that though some saw the NRA as corporatist, ${ }^{224}$ antitrusters had hopes for it too. ${ }^{225}$ The incoherence of the vision behind the NRA was reflected in and compounded by its dismal administration, which made it a failure at organizing the economy or bringing about economic recovery. ${ }^{226}$ The claim that the NIRA proposed to abolish market capitalism is silly. It simply added the public stamp of approval to cartels.

Ackerman also seems to say the Supreme Court was solely responsible for FDR's shift in emphasis in 1935. He initially quotes Leuchtenburg to the effect that the death blow to the NRA in Schechter was " the final goad' to a new collective effect by the President and Congress to give a clearer shape to the New Deal." ${ }^{227}$ In the accompanying note, Ackerman conscientiously observes: "We can never know, of course, whether Roosevelt and Congress would have regained the initiative without the assistance of the judicial dialectic. The President had, for example, already decided to support the Wagner Act a week before Schechter; and Social Security was long in the works." ${ }^{228}$ Yet eight pages later in the text, he maintains that "[o]nly in response to the Supreme Court did Roosevelt and the New Dealers rethink their course." 229

America's foremost experiment with corporatism."); Philippe Schmitter, Still the Century of Corporatism?, in TRENDS TOWARD CORPORATIST INTERMEDIATION 30 (PHIIPPE SCHMITTER \& GERHARD LEHMBRUCH eds., 1979) (describing the NRA as an "abortive attempt to encourage corporatist forms of policy-making during the early New Deal").

222. COLIN GORDON, NEW DEALS: BUSINESS, LABOR, AND POLITICS IN AMERICA, 19201935, at 31 (1994). But see James Q. Whitman, Of Corporatism, Fascism, and the First New Deal, 39 AM. J. COMP. LAW 747 (1991) (providing an account supporting Ackerman's portrayal of the First New Deal and especially the NRA as corporatist).

223. Alan Brinkley, The Two World Wars and the Idea of the State, THE LIBERAL PERSUASION: ARTHUR SCHLESINGER, JR., AND THE CHALLENGE OF THE AMERICAN PAST 127, 132 (John Patrick Diggins ed., 1997); see also LEUCHTENBURG, The New Deal and the Analogue of War, in LEUCHTENBURG supra note 38, at 35, 56-57 (pointing out the parallels between the War Industry Board and the National Recovery Administration).

224. See BRAND, supra note 221, at 11, 19.

225. See Ellis W. Hawley, The New Deal and tHe Problem of Monopoly 47-51 (1966).

226. See GoRDON, supra note 222, at 3, 193, 201; HAWLEY, supra note 225, at 130-46; Colin Gordon, Rethinking the New Deal, 98 CoLUM. L. REv. 2029, 2038 (1998) (reviewing 2 ACKERMAN, supra note 1) (criticizing Ackerman's description of the NRA). This is not to deny Ackerman's point that despite the unpopularity of the NIRA and NRA, Roosevelt was still irritated by the Court's opinion in Schechter. See 2 ACKERMAN, supra note 1, at 298.

227. 2 ACKERMAN, supra note 1 , at 302 .

228. 2 id. at 480 n.67.

229. 2 id. at 310 . 
Certainly other forces had an impact on the New Dealers' 1935 legislative agenda. For example, the NRA's failure to bring recovery, the wishes of the more liberal members of Congress elected in the 1934 midterm elections, and Roosevelt's hope of blunting the threat posed by the redistributive schemes of Huey Long and Francis Townsend also helped to explain the Administration's support for the 1935 agenda. ${ }^{230}$ Though Ackerman curiously does not acknowledge it, so did "the People" themselves, namely, as William Forbath has said, workers speaking the language of "social citizenship." 231 Leuchtenburg's characterization of Schechter as only "a final goad" to the New Dealers is the correct one. ${ }^{232}$

Further, Ackerman exaggerates what happened in 1935. This is not to deny the significance of that year's legislative accomplishments but to say that he mischaracterizes them. Take, as an example, his statement that "the Social Security Act guaranteed all workers the prospect of a decent old age." 233 Self-employed workers, farm laborers, and domestic servants excluded from coverage under the Act would have been surprised to hear that. ${ }^{234}$ "[T] $[$ he ominous decision to base entitlements to the social insurance programs on wage earnings" meant that most women "were disenfranchised from social citizenship rights by their very positions in society." 235

And thanks to the synergy of the AFL and Southerners in Congress, what progress did the Wagner Act make to end discrimination in unions? Specifically, how much did the Act matter, and when? During the period when its constitutionality was unclear, employers hostile to unions ignored it. The shift towards mass-production unionization was due in large part to the tactics of workers themselves. Before the Jones \& Laughlin decision, the Wagner Act may have served largely to increase workers' confidence

230. Cf., e.g., PARRISH, supra note 217 , at 339-41.

231. Forbath, supra note 39, at 194; see also LIZABETH COHEN, MAKING A NEW DEAL: INDUSTRIAL WORKERS IN CHICAGO, 1919-1939, at 285-86, 364-65 (1990).

232. LEUCHTENBURG, FDR AND THE NEW DEAL, supra note 218, at 150.

233. 2 ACKERMAN, supra note 1 , at 302.

234. In part, the exclusions reflected the influence of the South on the legislation as it moved through Congress. See JiLl Quadagno, The TRANSFormation OF Old AgE SeCuRITY: Class AND POLITICS IN THE AMERICAN WELFARE STATE 115-16 (1988). For a discussion of how Roosevelt's reliance on southern elites preserved the Old South, see BRUCE J. SCHULMAN, FROM COTTON Belt to SUNBELT: FEDERAL POLICY, ECONOMIC DEVElopMENT, AND THE TRANSFORMATION OF THE SOUTH, 1938-1980, at 14-38 (1991); and Ira Katznelson et al., Limiting Liberalism: The Southern Veto in Congress, 1933-1950, 108 POL. SCI. Q. 283 (1993), which demonstrates how congressional Southerners restricted the progress that their party could make on civil rights and labor questions.

235. LINDA GORDON, PITIED BUT NOT ENTTTLED: Single MOTHERS AND THE HISTORY OF WELFARE 1890-1935, at 291 (1994). I leave aside here the impact of the act on welfare. See id. at 283-85, 301-03. 
that the government was on their side-an important point, but a political rather than a legal one. ${ }^{236}$

Indeed, Ackerman's celebration of the New Deal is sharply at odds with the historiography. Leuchtenburg's FDR and the New Deal ${ }^{237}$ was the most influential book in inaugurating this generation of historians' debate over the achievements of Roosevelt's program. ${ }^{238}$ " The New Deal achieved a more just society by recognizing groups which had been largely unrepresented-staple farmers, industrial workers, particular ethnic groups, and the new intellectual-administrative class," ${ }^{239}$ Leuchtenburg concluded: "Yet this was still a halfway revolution; it swelled the ranks of the bourgeoisie but left many Americans-sharecroppers, slum dwellers, most Negroes-outside of the new equilibrium." 240

That was an insight that the New Left ran with later in the decade, ${ }^{241}$ paying no attention to constraints on the New Deal, such as the Court, ${ }^{242}$ which Leuchtenburg had illuminated. Presentist New Left historians made hay with Leuchtenburg's point, reading their own disenchantment with 1960s liberalism back into the 1930s to say that the New Deal represented a

236. See DAVID BRODY, The Emergence of Mass-Production Unionism, in DAVID BRODY, WORKERS IN INDUSTRIAL AMERICA: ESSAYS ON THE TWENTIETH CENTURY STRUGGLE 82, 10307 (1980).

237. LEUCHTENBURG, FDR AND THE NEW DEAL, supra note 218.

238. The book was a brilliant synthesis, compact and readable, but it was noticed at least as much for its critical stance as for its scholarly and stylistic virtues. Not since Broadus Mitchell's Depression Decade (1947) had a leading scholar found so many shortcomings in the New Deal record. At most points Leuchtenburg concluded that the situation had not permitted much more than the New Dealers had achieved, but his candid attention to the limited effects of New Deal recovery and reform measures sharply influenced interested scholars.

Otis L. Graham, Jr., Introduction to THE NEw DEAL: THE CRITICAL IssuES at ix, xiii (Otis L. Graham, Jr. ed., 1971).

239. LEUCHTENBURG, FDR AND THE NEW DEAL, supra note 218, at 347.

240. Id. More recently, responding to the New Left's position, Leuchtenburg has sometimes given greater attention to the achievements of the New Deal. See WILLIAM E. LEUCHTENBURG, The Achievement of the New Deal, in LEUCHTENBURG, supra note 38, at 236, 279.

241. The outstanding example is Barton Bernstein's scathing critique of FDR and the New Deal for "[o]perating within very safe channels," not simply avoiding Marxism and socialism, but stopping "far short of other possibilities-communal direction of production or the organized distribution of surplus." Barton J. Bernstein, The Conservative Achievements of Liberal Reform, in THE NEw DEAL: THE CRITICAL ISSUES, supra note 238, at 147, 158. Bernstein dismissed Roosevelt and most New Dealers as "doctrinaires of the center," who limited their experiments at social reform "to cautious excursions. Usually opportunistic and frequently shifting, the New Deal was restricted by its ideology. It ran out of fuel not because of the conservative opposition, but because it ran out of ideas." Id.

242. Had the New Left historicans paid the Hughes Court any attention, they might have found that its overal record, as well as that of its most conservative members, supported the left's argument that New Deal reforms were less wide-ranging than liberal historians had maintained. "[T] he Hughes Court at times anticipated the concerns of a later generation with the bureaucratic state, the abuses of private power, racial discrimination, and defects in the criminal justice system." Parrish, supra note 41, at 303; see also Cushman, The Secret Lives, supra note 1, at 560 (pointing to the liberal record of the Hughes Court). 
"raw deal" for the one-third of the nation that FDR had promised to help. ${ }^{243}$ Today, however, there is little enthusiasm for the broad argument that the New Deal represented a triumph for "corporate liberalism," 244 though few would deny that some corporate interests tried to mold the New Deal state to their purposes. ${ }^{245}$

On the other hand, today, few consider the New Deal as revolutionary as Ackerman maintains, either. To quote Leuchtenburg, "[E]ven historians who dispute the New Left assertions agree that one can only take a melancholy view of the period." ${ }^{246}$ And as Alan Brinkley said recently, "[M]ost historians in the last two decades have accepted some variation of Leuchtenburg's stance of muted praise." ${ }^{247}$ Ackerman's description of the New Deal makes Leuchtenburg's sound positively sour in comparison.

Is this important? To law professors, perhaps not. Why should Ackerman waste his time on an internecine dispute between historians over the First and Second New Deal and the achievements of the New Deal when he is not even interested in the debate between internalists and externalists over the Court? I recognize that law professors turn outward for their own purposes and have called for a disciplined interdisciplinarity, which neither treats other disciplines as window dressing nor is absorbed by them. ${ }^{248}$ Nevertheless, there are several reasons that Ackerman needs to pay attention to the historians.

First, I agree with Martin Flaherty: "Legal arguments relying on economics, philosophy, or sociology are more convincing when they comport with the standards set by those disciplines. Nothing prevents the same point from applying to arguments based upon history." ${ }^{249}$ Ackerman undercuts the credibility of his general thesis when he supports it with work that historians will find unconvincing. Second, even if one disagrees with

243. See Jerold S. Auerbach, New Deal, Old Deal, or Raw Deal: Some Thoughts on New Left Historiography, 35 J.S. HIST. 18 (1969); Graham, supra note 238, at xi-xv; Otis L. Graham, Jr., New Deal Historiography: Retrospect and Prospect, in THE NEW DEAL: THE CRITICAL IssUES, supra note 238, at 171, 173-75; Parrish, supra note 41, at 302-03; Fred Siègel, The New Left, the New Right, and the New Deal, in THE LIBERAL PERSUASION: ARTHUR SCHLESINGER, JR., AND THE Challenge of THE AMERICAN PAST 150, 155-59 (John Patrick Diggins ed., 1997).

244. See, e.g., ALAN BRDKLEY, THE END OF REFORM: NEW DEAL LIBERALISM IN RECESSION AND WAR 291 n.32 (1995); COHEN, supra note 231, at 282.

245. See, e.g., Thomas Ferguson, Industrial Conflict and the Coming of the New Deal: The Triumph of Multinational Liberalism in America, in THE RISE AND FALL OF THE NEW DEAL ORDER 1930-1980, at 3 (Steve Fraser \& Gary Gerstle eds., 1989).

246. LEUCHTENBURG, The Achievement of the New Deal, in LEUCHTENBURG, supra note 38, at $236,242$.

247. ALAN BRINKLEY, Historians and the Interwar Years, in LIBERALISM AND ITS DISCONTENTS 111, 122-23 (1998).

248. See KALMAN, supra note 2, at 224, 239.

249. Martin S. Flaherty, The Most Dangerous Branch, 105 YALE L.J. 1725, 1749 (1996). 
Flaherty and me on this point, I follow him in falling back on a childhood aphorism: "[S]omething worth doing at all is worth doing well." 250

Third, if the question here is whether the response to New Deal legislation by both the Old Court and Roosevelt affected constitutional jurisprudence, it seems important to exercise care in characterizing both the legislation and historians' evolving views of its significance. For example, if the Wagner Act and Social Security were not the "revolutionary reforms" Ackerman contends, did the Supreme Court's decisions to uphold them represent constitutional transformations? Perhaps yes, perhaps not; recall Cushman's point about the "conservative" Justices' sympathy for Social Security. ${ }^{251}$

Finally, what is at issue in Transformations is the power of "the people" working through all branches of government to bring about constitutional change without using the procedures set forth in Article V. I suspect Ackerman exaggerates the accomplishment of the first term of the New Deal to inspire the people to work towards the general goal of "social justice in a liberal state" 252 without becoming overdependent on the Court. ${ }^{253}$ His account may prove pernicious in that it raises unrealistically high expectations for the kinds of constitutional change that can be accomplished through channels of which he approves. That may explain what William Forbath has described as Ackerman's studied silence on the text of his constitutional amendments, ${ }^{254}$ and whether the New Deal enacted a non-Article $\mathrm{V}$ amendment guaranteeing a right to welfare or redefined the concept of national citizenship. ${ }^{255}$ If I am correct, law professors may find it useful for their own purposes to explore whether the New Deal was as much of a watershed as Ackerman contends.

\section{Of Subsequent Elections and Supreme Court Appointments}

If Ackerman overemphasizes the role of the Court in painting a picture that inflates the New Deal's successes, he underemphasizes the role of

250. Id. at 1747. But see Mark Tushnet, Interdisciplinary Legal Scholarship: The Case of History-in-Law, 71 CHI-KENT L. REV. 909, 932-34, 935 n.105 (1996) (arguing that good lawyers' legal history can be judged by whether "[i]ts creators . . . have substantially affected the way we think about law," and it apparently does not even demand getting the facts right).

251. See CUSHMAN, supra note 1, at 30; see also supra note 75 and accompanying text (noting that Justices Van Devanter and Sutherland were part of the seven-person majority voting to uphold the old-age provisions of the Social Security Act).

252. See BRUCE A. ACKERMAN, Social JuStiCE IN THE LibERAL STATE (1980).

253. See infra note 302 and accompanying text.

254. See Forbath, supra note 39, at 170; Richard Posner, This Magic Moment, THE NEW REPUBLIC, Apr. 6, 1998, at 32, 35. Judge Posner's piece was aptly summarized by Scott Powe as concluding that "compared to Ackerman's textless world, hypertextualism looks pretty good." L.A. Powe, Jr., Ackermania or Uncomfortable Truths?, 15 CoNST. CoMM. 547, 568 (1998).

255. See Forbath, supra note 39 , at 170. 
Court-packing in causing the New Dealers' congressional defeats in 1938. Court-packing was an important issue that year, and not one that helped the President. According to a recent book on the Republican Party during the New Deal, "Republican candidates continued to criticize the court reform proposal, making the spectre of 'one-man government' a recurrent theme." 256 Of course Court-packing was not the only flash point; the sit-down strikes, the President's attempt to "purge" his party of conservatives, and the "Roosevelt recession" also help to explain the success of conservative Southern Democrats and the Republicans' resurrection in the election. ${ }^{257}$

Thus, the suggestion that 1938 can be viewed as a "consolidating election" vis-à-vis Court-packing is odd. In fact, it appears that if 1937 witnessed the beginning of a "constitutional moment," the moment ended with the congressional elections of 1938. Assume, for a minute, that Scott Powe has correctly sythesized the substance of the New Deal transformation in two constituitonal amendments. Powe's "Amendment One" reads: "[1] Congress shall have the power to regulate the economy in the general welfare. [2] A Congressional determination of the general welfare shall not be open to challenge in any court of law." 258 According to "Amendment Two," "The States shall have the power to regulate their economies in the general welfare, so long as the regulation does not interfere with Congressional policies or unduly interfere with interstate commerce." ${ }^{259}$ If Ackerman rightly contends that real transformation of commerce clause jurisprudence occurred after the 1938 elections, and if I correctly argue that the 1938 elections reflected more of a repudiation than a consolidation of FDR's 1937 challenge of the Court, then "the people" may have approved Amendment One without approving Amendment Two. Of course, that does not matter if one agrees with Lawrence Lessig that we need no constitutional amendment equivalents to constitutionalize the New Deal, ${ }^{260}$ a matter I leave to the law professors.

While the Court was an issue that hurt Roosevelt in the 1938 election, it had little bearing on voters' selections two years later, as Ackerman indicates. ${ }^{261}$ Foreign policy had become the central issue, the Court irrelevant. Taft did not receive the nomination because, in the words of his

256. Clyde P. WeEd, THe Nemesis of Reform: THE REPublican PARTY DuRING tHe NEW DEAL 196 (1994).

257. LEUCHTENBURG, FDR AND THE NEW DEAL, supra note 218, at 250-72.

258. Powe, supra note 254, at 567.

259. Id.

260. See Lessig, supra note 14 , at $450-51,472$.

261. See 2 ACKERMAN, supra note 1 , at 357 . 
biographer, he possessed "two handicaps that pulled him back. One was his image. The other was the state of the world at the time." 262

Next to Taft, even Herbert Hoover seemed a colorful person, if not a person with a colorful life. ${ }^{263}$ In promoting Willkie as a vibrant internationalist, Time characterized Taft as "a tortoise," who heaped "one ineptitude on another." ${ }^{264}$ Nor did Taft's isolationism and his sometime insistence that the Nazis posed no danger to the United States help him. ${ }^{265}$ The Republicans chose Willkie not only because, by the time they met in Philadelphia at the end of June, France had fallen and Britain stood alone against Hitler, but also because they thought the personable Willkie had the best chance against Roosevelt. ${ }^{266}$ What Ackerman refers to as the Republicans' disinclination "to refight the constitutional battles of the 1930s," ${ }^{267}$ counted for virtually naught. Therefore, it also seems peculiar to regard 1940 as a "consolidating election" vis-à-vis the Roosevelt Court.

How, then, do we explain the easy congressional approval of Roosevelt's appointments to the Court? Ackerman has given us one way of understanding it, and perhaps it is the correct one. He may be right to say that the conservative coalition of Southern Democrats and Republicans in the Senate voted overwhelmingly to confirm Roosevelt's "emphatic[ally] liberal[]" appointees to the Court because they realized that the People had awarded Roosevelt a mandate to constitutionalize the New Deal. ${ }^{268}$ (Unfortunately, perhaps Senators did not realize that Roosevelt's inattentiveness to jurisprudential, as opposed to political positions, would

262. James T. PATterson, Mr. Republican: A BIOGRaphy OF Robert A. TAFT 213 (1972).

263. As Schlesinger writes of Hoover's early experiences as a mining engineer:

It was a Richard Harding Davis life, but Hoover was hardly a Richard Harding Davis hero. Contained, wary, enormously capable and efficient, with round face, hazel eyes, straight mouse-colored hair, and broad shoulders, he transmuted all adventure into business, as a Davis hero would transmute all business into adventure. His manner, except among old friends to whom he had given his confidence, was forbidding; and, even among old friends, he remained reserved.

ARTHUR M. SCHLESINGER, JR., THE CRISIS OF THE OLD ORDER, 1919-1933, at 78 (1957).

264. PATTERSON, supra note 262, at 215.

265. See id, at 217.

266. See Robert E. Burke, Election of 1940, in THE COMING TO POWER: CRITICAL PRESIDENTIAL ElECTIONS IN AMERICAN HISTORY 355 (Arthur M. Schlesinger, Jr. ed., 1971).

267. 2 ACKERMAN, supra note 1 , at 358 .

268. 2 id. at 355. I can imagine Charles E. Clark and William O. Douglas-not to mention Fred Rodell!- spinning in their graves as we sit in the Yale Law School rejoicing in Roosevelt's appointment of the "liberal" Frankfurter. Nevertheless, Frankfurter did indeed seem liberal at the time of his nomination and, to the best of my knowledge, New Dealers and realists alike rejoiced in his appointment. Although I wonder if the nominees' beliefs were important to the confirmation process, see infra note 270 and accompanying text, I do agree with Ackerman that Roosevelt generally paid closer attention than many other Presidents to something we might consider political "ideology" in the nomination process. See also HENRY J. ABRAHAM, JUSTICES AND PRESIDENTS: A POLITICAL HISTORY OF APPOINTMENTS TO THE SUPREME COURT 210 (2d ed. 1985) (noting that FDR sought loyalty to his philosophy from his appointees). 
produce a bitterly divided Court, which fought its battle in the conference room, in opinions, and through publications by surrogates. ${ }^{269}$

But there may be other explanations. One is that Ackerman is anachronistic. Perhaps, save for the possible odd exceptions of the Brandeis, Parker, Haynesworth, and Fortas Chief Justiceship nominations, "ideology" proved relatively unimportant to the confirmation process in the twentieth century until the Bork hearings. ${ }^{270}$ Certainly it seems relevant that of the twenty-five instances in which the Senate has rejected or forced a President to withdraw a Supreme Court nomination, only five have occurred since $1895 .{ }^{271}$ While the idea of a "spineless Senate" rubber-stamping presidential appointments to the Supreme Court in the twentieth century before Bork is surely overblown, ${ }^{272}$ it may not be the "myth" that Laurence Tribe maintains it is either. ${ }^{273}$

Another explanation for Senators' acquiescence is that they had bigger fish to fry. Consider that the Senate considered the appointments of Justices Frankfurter and Murphy at the same time it was reviewing the credentials of Progressive Thomas R. Aimlie for a position on the Interstate Commerce Commission. All three were "stamped with a radical stamp," conservative Senator Josiah Bailey said privately. ${ }^{274}$ Nevertheless, the Senate blocked only Aimlie's appointment and confirmed Frankfurter and Murphy. "We must not waste our energy by fighting out issues on the smaller matters, nor should we do anything to take from the President the responsibility for the consequences of his six years," Bailey explained. ${ }^{275}$ " So, if we appear to be 'yielding, just remember, we are 'stooping to conquer."”276

269. See generally PHILIP J. COOPER, BATTLES ON THE BENCH: CONFLICT INSIDE THE SUPREME COURT (1995) (describing bitter divisions within the Supreme Court); Melvin I. Urofsky, Conflict Among the Brethren: Felix Frankfurter, William O. Douglas and the Clash of Personalities and Philosophies on the United States Supreme Court, 1988 DUKE L.J. 71 (detailing the clash between Justices Frankfurter and Douglas).

270. See ETHAN BRONNER, BATTLE FOR JUSTICE: HOW THE BORK NOMINATION SHOOK AMERICA (1989); Bruce A. Ackerman, Transformative Appointments, 101 HARV. L. REV. 1164, 1167-70 (1988). I say possible because I am not sure how important ideology was in the failure of all these nominations. See, e.g., JOHN MASARRO, SUPREMELY POLITICAL: THE ROLE OF IDEOLOGY AND PRESIDENTIAL MANAGEMENT IN UNSUCCESSFUL SUPREME COURT NOMINATIONS 135 (1990) (noting that "ideological opposition alone would very likely not have been sufficient to bring about the Senate's unfavorable actions" in the cases of the Fortas, Haynesworth, and Carswell nominations and pointing to the importance of poor timing and presidential mismanagement in sinking those nominations).

271. The rejects were Parker, Haynesworth, Carswell, Bork, and Fortas. The Ginsburg nomination was never formally submitted to the Senate, and the Senate took no action on the Thornberry nomination because of its failure to confirm Fortas as Chief Justice.

272. Laurence Tribe, God SAVe This Honorable Court: How the Choice of SUPREME COURT JUSTICES SHAPES OUR HISTORY 77 (1985).

273. Id.

274. PATTERSON, supra note 102, at 299.

275. Id.

276. $I d$. 


\section{Farewell to Reform}

On the larger matters, conservatives usually prevailed, bringing us to my major problem with Ackerman's history. Ackerman's attitude compares to Roosevelt's in 1939. Remarking on his Court's decisions upholding the New Deal, the President claimed he had "lost the battle but won the war." 277 I am more inclined to side with one historian, who concluded that, "[a]s matters turned out in Congress and party, it could better be said that he lost the battle, won the campaign, but lost the war." 278

No one has set out the disastrous consequences of Court-packing for the New Deal and the Roosevelt coalition better than Leuchtenburg. Courtpacking divided the Democrats and reformers; undermined middle-class and bipartisan support for the New Deal; and distracted FDR from the realm of foreign affairs at the same time that it increased congressional unwillingness to grant him discretion there. ${ }^{279}$ Its defeat shattered the sense of the President's invulnerability. 280 "The new Court might be willing to uphold new laws, but an angry and divided Congress would pass few of them for the justices to consider," Leuchtenburg said. ${ }^{281}$ "The whole New Deal really went up in smoke as a result of the Supreme Court fight," one New Dealer mourned. ${ }^{282}$

But more went up in smoke than Roosevelt's reform program. All of these consequences pale in importance next to the fact that Court-packing "helped blunt the most important drive for social reform in American history and squandered the advantage of Roosevelt's triumph in 1936" by welding together a bipartisan coalition of conservative Southerners and

277. LEUCHTENBURG, supra note 2, at 156.

278. JAMES MACGREGOR BURNS, ROOSEVELT: THE LION AND THE FOX 315 (1956).

279. See LEUCHTENBURG, supra note 2, at 157-61.

280. See BRINKLEY, supra note 244 , at 20 ; PATTERSON, supra note 102 , at $127,166$.

281. LEUCHTENBURG, FDR AND THE NEW DEAL, supra note 218, at 239.

282. LEUCHTENBURG, supra note 2, at 158 (quoting Henry Wallace); see also JOSEPH P. LASH, DEALERS AND DREAMERS: A NEw LOOK AT THE NEW DEAL 315 (1988) (reporting Tom Corcoran's conclusion that the Court fight caused the President's loss of Southern Democrats). After the Senate Judiciary Committee released its defiant report describing Roosevelt's Courtpacking bill as "a needless, futile, and utterly dangerous abandonment of constitutional principle" and arguing that it should be "emphatically rejected," Arthur Krock reported:

Since there were two ways of writing the report, the personal excoriation of the President is accepted by politicians here as a deliberate choice. And since it was possible to have conceded some merit to certain parts of the ... bill, the fact that none was admitted is taken for willingness on the part of the seven Democrats ... and those whom they represent to have a clean break, party-wise with Mr. Roosevelt. The sum of much experienced Washington opinion is that a large group of Democratic senators, who oppose the later extensions of the New Deal, are determined to take back party control in 1940.

BAKER, supra note 92, at 230 (quoting Senate Report and Arthur Krock). 
Republicans. ${ }^{283}$ "Even as the Court fight began they were edging around each other, doing a dance of political Romeos and Juliets." ${ }^{234}$ The Republicrats diluted and often blocked further attempts at reform until $1964,{ }^{285}$ and liberalism suffered as a result. No longer as concerned with developing a class-based agenda as they had been between 1933 and 1938, postwar liberals focused on ensuring consumption and pressing the Court to articulate individual rights. ${ }^{286}$

In fact, I suspect this loss points to the reason that as a political historian (and self-avowed liberal), I am so invested in the externalism explanation for the Court's shift. Court-packing proved the snowball triggering the 1937-1938 avalanche that blocked legislative reform at the national level until the 1960s. If we can at least say Court-packing may have caused a "switch" among the Justices, its high price becomes less painful.

One would not expect law professors to care as much about this as political historians. It is relevant, however, to academic lawyers. In closing off Congress as a locus for reform and helping to lessen the chance of electing a genuinely liberal President, Court-packing ensured that only an appointed body of elites, which did not serve at the pleasure of the people, could afford to redeem the "transformative promises" 287 of Roosevelt and his "closer continuer[s]." 288 The Court used the 1937 crisis to increase its power. ${ }^{239}$ Court-packing led to the revival of the "countermajoritarian dilemma." 290

283. LEUCHTENBURG, supra note 2, at 157. Elsewhere, Leuchtenburg has identified the Court fight as "probably the most important single event in the creation of the conservative coalition that brought the New Deal to a virtual standstill by 1938." LEUCHTENBURG, supra note 38, at 224.

284. BAKER, supra note 92 , at $183-84$.

285. See generally LEUCHTENBURG, supra note 2, at 158 (describing the impact of the "bipartisan anti-New Deal coalition").

286. See BRINKLEY, supra note 244 , at $6,10,170,268-71$.

287. 2 ACKERMAN, supra note 1 , at 391 .

288. 2 id. at 387.

289. William Lasser observes that the Court could do so "because virtually no oneincluding Roosevelt—sought to harm it." WILLIAM LASSER, THE LIMITS OF JUDICIAL POIVER: THE SUPREME COURT IN AMERICAN POLITICS 160 (1988). As in the cases of slavery and Reconstruction, "the nation had no real complaint with judicial power [in the New Deal] but only a disagreement with the Court over critical issues of national policy. Once those issues were resolved, the Court was quickly and unmistakably put back on its pedestal." Id.

290. Barry Friedman is exploring the "puzzling paucity of countermajoritarian criticism" during the New Deal, as compared with the Populist and Progressive eras. Friedman, supra note 116, at 24. Though the Court struck down legislative measures during both the New Deal and the Populist/Progressive periods, during the New Deal, complaints that the Court was a countermajoritarian force thwarting the will of the people took a back seat to the critique that "recalcitrant judges, old judges, horse-and-buggy judges ... just could not get it right. It was judges who were attacked during the New Deal, not courts, and not the institution of judicial review." Id. at 8. 


\section{THE PERSISTENCE OF PROCESS}

\section{A. Ackerman and the "Countermajoritarian Dilemma"}

The countermajoritarian dilemma has shaped the professional life of Ackerman, who dedicated one of his earliest books to Alexander Bickel ${ }^{291}$ and made one of the first attempts at identifying the members of the legal process school. ${ }^{292}$ As Bickel set out the problem in its most famous formulation:

The root difficulty is that judicial review is a counter-majoritarian force in our system. There are various ways of sliding over this ineluctable reality. Marshall did so when he spoke of enforcing, in behalf of "the people," the limits that they have ordained for the institutions of a limited government. And it has been done ever since in much the same fashion by all too many commentators. Marshall himself followed Hamilton, who in the 78th Federalist denied that judicial review implied a superiority of the judicial over the legislative power-denied, in other words, that judicial review constituted control by an unrepresentative minority of an elected majority. "It only supposes," Hamilton went on, "that the power of the people is superior to both; and that where the will of the legislature, declared in its statutes, stands in opposition to that of the people, declared in the Constitution, the judges ought to be governed by the latter rather than the former." But the word "people" so used is an abstraction. Not necessarily a meaningless or a pernicious one by any means; always charged with emotion, but nonrepresentational-an abstraction obscuring the reality that when the Supreme Court declares unconstitutional a legislative act or the action of an elected executive, it thwarts the will of representatives of the actual people of the here and now; it exercises control, not in behalf of the prevailing majority, but against it. That, without mystic overtones, is what actually happens. It is an altogether different kettle of fish, and it is the reason the charge can be made that judicial review is undemocratic. ${ }^{293}$

291. See BRUCE A. ACKERMAN, PRIVATE PROPERTY AND THE CONSTTTUTION (1977).

292. See Bruce A. Ackerman, Law and the Modern Mind by Jerome Frank, DAEDALUS, Winter $1974,119,123 \& 128 \mathrm{n} .26$. The other early attempt to identify process jurisprudents was made by G. Edward White. See G. Edward White, The Evolution of Reasoned Elaboration: Jurisprudential Criticism and Social Change, 59 VA. L. REv. 279, 286-91 (1973).

293. AlEXANDER M. BICKEL, THE LEAST DANGEROUS BRANCH: THE SUPREME COURT AT THE BAR OF POLITICS 16-17 (1962). 
Whereas Bickel rejected "the People" and popular sovereignty as abstractions, Ackerman wants to imbue those concepts with meaning. ${ }^{294}$ Throughout his book, Ackerman extols the way the People have unconventionally changed the meaning of the Constitution in America's past. ${ }^{295}$ Without their creativity, he cannot see "how Americans could have democratically transformed themselves from a decentralized Union of white men to a Nation of all races and creeds whose government-on both federal and state levels-is actively engaged in assuring a better life for all citizens." 296

What's done is done. Like legal process scholars, such as Henry Hart in the 1930s, Ackerman admires Americans' imaginativeness in amending the Constitution outside Article V during the New Deal. Recall that Hart and Frankfurter, who were to become the preeminent exponents of the legal process school, wrote unsigned editorials during the 1930s in The New Republic attacking the old Court. ${ }^{297}$ Hart also publicly supported Roosevelt's Court-packing plan, arguing there was no alternative. "Responsible men have earnestly to ask themselves whether the increasing popular dissatisfaction with the Court may not so undermine respect for the Court and for all courts, as to threaten damage far exceeding anything which by any calm view, may be anticipated from President Roosevelt's suggestion." 298

Ackerman's position differs from Hart's in that Ackerman argues that something good came out of the Old Court's intransigence. But Ackerman draws the same moral from Court-packing as Justice Frankfurter and Hart: No Supreme Court should act as a "superlegislature" - for either liberals or conservatives. ${ }^{299}$ Thus, Justice Frankfurter, Hart, Bickel, and other legal process scholars during the 1950s and 1960s decried the Warren Court as the liberal, activist analogue of the conservative, activist Court of the 1930s.

294. Cf. James E. Fleming, We the Unconventional American People, 65 U. CHI. L. REV. 1513, 1541 (1998) (equating Ackerman's view with Bickel's "impoverished" concepts of democracy and interpretation and maintaining that "Ackerman is hobbled by the quest for "the possibility of popular sovereignty,' just as Bickel was haunted by the 'counter-majoritarian difficulty"').

295. See 2 ACKERMAN, supra note 1 , at 384.

296. 2 id. at 389.

297. Hart's editorials are collected in the Henry M. Hart Papers, Harvard Law School, Box 29, Folders 1-3, cited in KALMAN, supra note 2, at $253 \mathrm{n} .12$.

298. Henry M. Hart, The United States Supreme Court: An Argument on the President's Side, HARV. ALUMNI BULL. (on file with Harvard Law School, in the Henry M. Hart Papers, Box 30, Folder 8), cited in KALMAN, supra note 2, at $253 \mathrm{n} .11$.

299. See Robert Harrison, The Breakup of the Roosevelt Court: The Contribution of History and Biography 333 (1987) (unpublished Ph.D. dissertation, Columbia University) (on file with The Yale Law Journal), cited in KALMAN, supra note 2, at 253 n.11. 


\section{B. "Never Again!"}

So, too, the Ackerman of the 1990s swears off Roosevelt's tactics. He is especially eager to avoid the "Rooseveltian precedent" for constitutional change in the future, he tells us. ${ }^{300}$ FDR's manner of changing the Constitution through transformative appointments that yielded amendment-analogues "probably worked a lot better than the formal amendments Americans were likely to enact in the 1930's." ${ }^{301}$ But the President's vision of constitutional change assigned "too active a role to the Supreme Court and too passive a role to the President, Congress, and the voters." ${ }^{302}$

That leads Ackerman to his proposals for taking "the sting out of the Rooseveltian precedent." ${ }^{303}$ First, he supports the adoption of super-majority requirements for Supreme Court confirmations. If two-thirds of the Senate had to approve nominees, an "ideological President with a weak mandate" would be unable to "ram through a constitutional revolution" with only the support of a bare majority. ${ }^{304}$ Because the opposing party generally holds at least a third of the Senate, Ackerman's precondition would also thwart presidential efforts to realize their social visions by appointing "constitutional visionaries. They would be obliged to consult with the political opposition and select distinguished professionals who would adopt an evolutionary approach to constitutional interpretation." ${ }^{305}$

More sweepingly, Ackerman advances a popular sovereignty initiative by which a successfully reelected President could "signal a constitutional moment" ${ }^{306}$ by proposing amendments to the Constitution during his or her second term. If approved by a majority of both Houses, preferably by two-thirds vote, those amendments would appear on the ballots during the next two presidential elections. If voters approved them at the elections (each vote counting as much as any other, without regard to the voter's state of origin), the amendments would be added to the Constitution. "The aim is to register the considered judgments of We the People of the United States." ${ }^{307}$

With these proposals, Ackerman shows that his project is more than an attempt to constitutionalize the New Deal and rescue it from "the junkheap of historical irrelevancy" to which conservative Republicans would consign

300. 2 ACKERMAN, supra note 1 , at 408 .

301. Id. at 348 .

302. Id. at 408 .

303. Id. at 407.

304. Id.

305. Id. (emphasis added).

306. Id. at 410 .

307. Id. 
it. ${ }^{308}$ For one thing, the constitutional principles of New Deal liberalism, even as supplemented by the Civil Rights Revolution are a far cry from his own vision of social justice in a liberal state, which would break the hold of a familiar vision of the welfare state by guaranteeing each American reaching early adulthood a one-time stake of $\$ 80,000$ financed by a $2 \%$ annual wealth $\operatorname{tax}^{309}$ (I query, however, whether in the absence of the enactment of his "stakeholder society," Ackerman considers the New Deal an acceptable minimal alternative and may have turned to history, and perhaps originalism, to legitimate it.) For another, by the very nature of his proposals, he demonstrates that "it should be clear enough" that his history and prescriptions "could be used to legitimate the root and branch repudiation of New Deal liberalism by some future Kemp-Gingrich-Lott trio." 310

\section{CONCLUSION: WHAT MANNER OF MAN?}

What, then, drives Ackerman? "I am in it as a not-so-humble servant of the American People, who seeks to repay part of the great debt I have incurred as I rose out of a poor neighborhood in the Bronx to my present position of local eminence in New Haven," he confides engagingly. ${ }^{311}$ Since my roots are in the Bronx too, one generation removed, I may be prejudiced. I will say that if I could be certain that everyone in society were as brilliant and caring as Ackerman's parents must have been to produce him, I might endorse his proposals. But I now hail from a state in which popular democracy and referenda have undercut public education and affirmative action. In California, only the federal courts have kept affirmative action alive and prevented public schools from closing their doors to the children of undocumented immigrants. ${ }^{312}$

Under those circumstances, the safest route seems to remain a child of the federal courts and the Warren Court in particular. The position also seems consistent with externalism: If one emphasizes the overlap of law and politics and accepts the growth of a Court-centered society as a fact of life in the post-New Deal era, why not hope for a resurgence of courts that will reach one's preferred results? I know my position smacks of elite

308. Ackerman, supra note 43, at 1535. For one critique of Ackerman's position, see Suzanna Sherry, The Ghost of Liberalism Past, 105 HARV. L. REv. 918 (1992) (reviewing 1 ACKERMAN, supra note 7 (1991)).

309. See generally Bruce ACKERMAN \& ANNE AlstotT, THE STAKeHOLdER SOCIETY (1999) (elaborating and defending that proposal).

310. Ackerman, supra note 43, at 1535.

311. Id.

312. For a discussion of the impact of Propositions 13, 187, and 209 on California, see LYDIA CHÁVEZ, THE COLOR BIND: CALIFORNIA's BATTLE To END AFFIRMATIVE ACTION (1998); and PETER SCHRAG, PARADISE LOST: CALIFORNIA'S EXPERIENCE, AMERICA'S FUTURE (1998). 
liberal paternalism. So what? As FDR might have put it, "mais tu sais, me voilà!" ${ }^{313}$

Further, as someone who works on the history of legal realism and who is not subjected to the diet of "realist banalities," such as the slogan "[e]verthing is politics," 314 which enervate the life of Ackerman the law professor, my sympathies with the realist impulse undergirding the Warren Court remain stronger than his. That is not saying much. Like the legal process scholars, ${ }^{315}$ Ackerman has long had little good to say for legal realism. At least since Reconstructing American Law, he has been calling upon the legal profession to jettison "a shallow Realism that has outlived its time." 316

Ackerman's hostility to realism may be as important in accounting for his prescriptions as his Bronx roots. It may even be related to his Bronx roots: I have always thought it interesting that of five important contemporary legal thinkers from the Bronx-Bruce Ackerman, Alexander Bickel, Owen Fiss, Albert Sacks, and Morton Horwitz-four could be counted members of the Legal Process school. Perhaps there was something about the twin emphases on democracy and meritocracy that were the staples of a Bronx upbringing a generation ago (at least, so I have inferred from the many paeans to the "old" CCNY I have heard through the years) that made process theory seem especially appealing. (Since democracy and meritocracy also drove the New Deal, that may help us understand Ackerman's enthusiasm for that period in American history.)

My speculations about daily life in the Bronx should not distract us from Ackerman's antipathy to realism. Consider his hostility to transformative appointments as a mechanism for future change. Leave aside his contention that the super-majority requirement would make it more probable that the Senate would approve "distinguished professionals" than "constitutional visionaries." 317 (It seems to me, though, that while the two-thirds requirement might give potentially transformative appointees less of a chance of surviving a Senate vote, it might just as easily promote the selection of political hacks everyone could agree on as well-respected professionals.)

313. So FDR wrote his mother when she objected to his early marriage. See SCHLESINGER, supra note 263 , at 325 .

314. 2 ACKERMAN, supra note 1 , at 418.

315. See, e.g., NEIL DUXBURY, PATTERNS OF AMERICAN JURISPRUDENCE 212 (1995) (pointing out that despite realism's interrelationship with process theory, "the move towards process thinking [is] regarded generally as a response to the failure of realism"). That seems to me to capture the way the process theorists regarded their move toward process theory.

316. BRUCE A. ACKERMAN, RECONSTRUCTING AMERICAN LAW 110 (1984). For a critique of Ackerman's relation to realism, see G. Edward White, Book Review, 34 J. LEGAL EDUC. 731, 731-34 (1984), which contends that Ackerman ignored the meaning of realism in Reconstructing American Law and points out the affinities between Ackerman's views and process theory.

317. 2 ACKERMAN, supra note 1 , at 407. 
"Do not pin your hopes on the return to power of a Warren Court," one can hear Ackerman warning liberals. (One is reminded of Alexander Bickel cautioning his students in the 1960 s that "federal judges were not inevitably "little Earl Warrens in black robes." ) $)^{318}$ Theirs are friendly warnings: To some extent, both Ackerman and Bickel, though hostile to the legal realism associated with the Warren Court's legal and political liberalism, ${ }^{319}$ sympathize with the reformers' ends. But for Ackerman, transformative appointments nevertheless possess three problems: "[1]egal focus; institutional weight; popular responsiveness." ${ }^{320}$ The charged nature of the contemporary confirmation process does not encourage serious discussion of substantive issues. ${ }^{321}$ Thus, "the ease with which Senatorial confirmation battles can obscure the underlying issues," combined with actuarial contingencies in the form of death and resignation from the Court, may make it "too easy for randomly selected Presidents," who lack the mandate Roosevelt acquired, to transform constitutional law. ${ }^{322}$ And finally, the old bugaboo: "Changing the Constitution by changing the Court is also less democratic, especially since the process of gaining Senatorial consent does not invite the mass participation properly required for a new constitutional beginning." 323

Thus, we have come back to Bickel: The real problem for Ackerman is that judges exercise too much power in a democracy. The related problem is that our legal culture teaches them and everyone else that "law is politics." Like Cushman, and like other members of the process tradition, Ackerman laments the contemporary absence of attention to craft, and the failure to appreciate that law matters. For all his concern with democracy, Ackerman may feel it even more imperative to ensure the appointment of the right judges, who see law as he does-safely distinguished from politics.

Ackerman's Bickelian prudentialism, which accounts for his appreciation of, and attempt to legitimate precedent, has led him to create a new recipe, suited both to his Bronx childhood and his loyalty to the legal process. ${ }^{324}$ Take a base of history; add "distinguished" and "professional" meritocratically selected judges, who as distinguished professionals would

318. Dedication, 84 Yale L.J. (n.p.) (Dec. 1974) (quoting Bickel).

319. For Bickel's relationship with realism, see, for example, BICKEL, supra note 293 , at 81 84; and KALMAN, supra note 2, at 263-64 n.48. For his relationship to political and legal liberalism, see KALMAN, id. at 48-49, 268-70 n.65.

320. Ackerman, supra note 270 , at 1182 .

321. See 2 ACKERMAN, supra note 1 , at $404-05$.

322. 2 id. at 405 .

323. 2 id. (emphasis added).

324. See, e.g., $2 \mathrm{id}$. at 397-402 (taking the plurality in Planned Parenthood v. Casey, 505 U.S. 833, 861-62 (1992), to task for maintaining that the Lochner-era rested on the old Court's erroneous assessment of facts); see also KALMAN, supra note 2, at 228 (discussing Ackerman's appreciation of precedent). 
(Ackerman implies) have no choice but to "adopt an evolutionary approach to constitutional interpretation" he endorses; ${ }^{325}$ mix with the will of the people; and we get a new constitutional dish. As ingenious as the presentation is, it remains one that we have seen before. It is warmed-over Bickel.

In the end, I find myself more skeptical even than Ackerman that his proposals will carry the day. ${ }^{326}$ Certainly, I am more dubious than he is that their success would benefit society. But I am awed by Ackerman's creative use of history and his citizenship in advancing them. 
